\title{
Non-Platinum Metal Complexes as Potential Anti-Triple Negative Breast Cancer Agents
}

\author{
Eva María Domínguez-Martís ${ }^{1}$, Diego Gabriel Mosteiro-Miguéns ${ }^{2}$, Lucía Vigo-Gendre ${ }^{1}$, \\ David López-Ares ${ }^{3}$, Manuel Freire-Garabal ${ }^{4}$, María Jesús Núñez-Iglesias ${ }^{4}$ and Silvia Novío ${ }^{4, *}$ \\ 1 Galician Public Health Care Service, Health Care Centre of Ordes, C/Ramón Ferreiro s/n, 15680 Ordes, \\ A Coruña, Spain; eva.dominguez2@hotmail.com (E.M.D.-M.); lucia.vigo.gendre@gmail.com (L.V.-G.) \\ 2 Badalona Serveis Assistencials, Family and Community Nursing, Health Care Centre of Morera-Pomar, \\ C/PERE III, No 1-7, 08915 Badalona, Barcelona, Spain; diegomoste@gmail.com \\ 3 Galician Public Health Care Service, University Hospital Complex of A Coruña (CHUAC), C/Xubias de \\ Arriba, 84, 15006 A Coruña, Spain; dlopares@gmail.com \\ 4 SNL Laboratory, School of Medicine and Dentistry, University of Santiago de Compostela, C/San Francisco \\ s/n, 15782 A Coruña, Spain; mjesus.nunez@usc.es (M.F.-G.); manuel.freire-garabal@usc.es (M.J.N.-I.) \\ * Correspondence: silvia.novio@usc.es; Tel.: +34-881812374
}

Received: 12 August 2018; Accepted: 18 September 2018; Published: 20 September 2018

\begin{abstract}
Breast cancer (BC) is the most common cancer in women worldwide, with a mortality rate that has been forecasted to rise in the next decade. This is especially worrying for people with triple-negative BC (TNBC), because of its unresponsiveness to current therapies. Different drugs to treat TNBC have been assessed, and, although platinum chemotherapy drugs seem to offer some hope, their drawbacks have motivated extensive investigations into alternative metal-based BC therapies. This paper aims to: (i) describe the preliminary in vitro and in vivo anticancer properties of non-platinum metal-based complexes (NPMBC) against TNBC; and (ii) analyze the likely molecular targets involved in their anticancer activity.
\end{abstract}

Keywords: antiproliferative activity; apoptosis; metal complexes; metastasis; treatment; triple negative breast cancer

\section{Introduction}

Breast cancer $(\mathrm{BC})$ is, despite therapeutic advances, the most common cancer among females (1.5 million women worldwide each year) and the leading cause of death from cancer in women (570,000 in 2015). Furthermore, its incidence is expected to rise in the coming decades [1]. This global increase in the $\mathrm{BC}$ burden is mainly attributed to exogenous factors such as reproductive and lifestyle factors; however, genetic risk factors such as mutations in breast cancer susceptibility gene 1 (BRCA1) and gene 2 (BRCA2), which are associated to tumors with more aggressive phenotypes, play an important role in the etiology of this type of cancer $[2,3]$.

$\mathrm{BC}$ is classified according to the expression of immunohistochemical markers in luminal $\mathrm{A}$, luminal B, HER-2 positive and triple negative subtypes, being the triple negative subtype further divided into A (luminal-like) and B (basal-like) [4,5] (Table 1). The basal-like cancers account for $60-90 \%$ of triple negative cases, with the BC subtype having the worst prognosis. Compared with the other subtypes, triple negative breast cancer (TNBC) is more likely to be diagnosed at a younger age; it is more frequently associated with mutations in the BRCA; it usually has rapid growth and large size; it frequently overexpresses genes involved in drug-desensitizing mechanisms (for example, ABCC1 or MRP1 (multidrug resistance protein 1)); and it has a high rate of early recurrence and of distant metastasis (brain, lung, bone, and liver), and a low disease-specific survival [6]. Furthermore, due to 
the lack of specific molecular targets in this subtype of BC [7], which makes its treatment difficult, chemotherapy remains an essential component for the management of TNBC, both adjuvant and neoadjuvant therapy $[8,9]$.

Table 1. Characterization of the main triple negative breast cancer (TNBC) cell lines according to the subtype and molecular features.

\begin{tabular}{|c|c|c|c|}
\hline Subtype & TNBC Cell Lines & Others Immunohistochemical Markers besides ER, PR and HER2 a & Tumor of Origin \\
\hline \multirow{15}{*}{ A } & BT-20 & WNT3 oncogene + , WNT7B oncogene + & Invasive ductal carcinoma \\
\hline & CAL148 & $\begin{array}{c}\text { CK } 7+\text {, CK } 8+, \text { CK } 17-\text { CK } 18+, \text { CK } 19+\text {, desmin -, endothel -, } \\
\text { EpCAM +, GFAP -, neurofilament -, vimentin - }\end{array}$ & Adenocarcinoma \\
\hline & DU4475 & $\begin{array}{c}\text { CK } 7-, \text { CK } 8+\text {, CK } 17-, \text { CK } 18+, \text { CK } 19-\text {, desmin -, endothel -, } \\
\text { EpCAM +, GFAP -, neurofilament -, vimentin - }\end{array}$ & Invasive ductal carcinoma \\
\hline & EMG3 & CK $5+$, CK $14+$, CK $18+$, CK $19-$, EMA +, P63+, SMA -, ESA +, EGFR + & Invasive ductal carcinoma \\
\hline & HCC1187 & EGP2 +, CK $19+$, p $53+++$ & Ductal carcinoma \\
\hline & HCC1599 & $\mathrm{EGP} 2+, \mathrm{CK} 19+, \mathrm{p} 53-$ & Ductal carcinoma \\
\hline & HCC1806 & p53 -, EGP2 +, CK $19+$, Ob-R + & Squamous carcinoma \\
\hline & HCC1937 & p53 -, EGP2 +, CK $19+$ & Ductal carcinoma \\
\hline & HCC2157 & $\mathrm{EGP} 2+, \mathrm{CK} 19+, \mathrm{p} 53+$ & Ductal carcinoma \\
\hline & KPL-3C & Keratins -, Vimentin - & Invasive ductal carcinoma \\
\hline & MA11 & e-cadherin + & Invasive lobular carcinoma \\
\hline & MDA-MB-436 & Tubulin + , actin + , ICAM +++ & Adenocarcinoma \\
\hline & MDA-MB-468 & EGFR +, TGF alpha +, Ki67 high & Adenocarcinoma \\
\hline & MFM223 & $\begin{array}{l}\text { CK } 7+\text { +, CK } 8+, \text { CK } 17-, \text { CK } 18+\text { +, CK } 19+\text {, desmin -, endothel -, } \\
\text { EpCAM +, GFAP -, neurofilament -, vimentin - }\end{array}$ & Carcinoma \\
\hline & SUM229PE & CK $8+$, CK $18+$, CK $19+$ & Ductal carcinoma \\
\hline \multirow{13}{*}{ B } & A17 & Vimentin,+ CK $14+, \mathrm{N}$-cadherin,+ COX $2+++$ & Carcinoma \\
\hline & BCM-2665A & $\mathrm{ALDH}+$ & Invasive ductal carcinoma \\
\hline & HCC1395 & p53 +, EGP2 +, CK $19+$ & Ductal carcinoma \\
\hline & HCC1739 & N.A. & Ductal carcinoma \\
\hline & HCC38 & p53 +, EGP2 +, CK $19+$ & Ductal carcinoma \\
\hline & HDQ-P1 & $\begin{array}{l}\text { CK } 7+, \text { CK } 8+, \text { CK } 17+, \text { CK } 18+, \text { CK } 19+\text {, desmin }- \text {, endothel }- \text {, } \\
\text { EpCAM +, GFAP -, neurofilament -, vimentin }+\end{array}$ & Invasive ductal carcinoma \\
\hline & Hs578T & $\begin{array}{c}\text { Ki67 low, e-cadherin low, claudin-3 low, claudinin-4 low, claudinin-7 low, } \\
\text { EGFR + }\end{array}$ & Invasive ductal carcinoma \\
\hline & MDA-MB-157 & WNT7B oncogene + , ICAM +++ & Medullary carcinoma \\
\hline & MDA-MB-231 & $\begin{array}{l}\text { EGFR +, TGF alpha +, CD44 +++, LHRH +++, WNT7B oncogene +, } \\
\text { ICAM-1 +++, Ki67 low, e-cadherin low, claudin-3 low, claudinin-4 low, } \\
\text { claudinin-7 low, alpha-V beta-3 integrin +, Ob-R }+\end{array}$ & Adenocarcinoma \\
\hline & OCUB-M & e-cadherin + , Laminin + & Carcinoma \\
\hline & SUM1315 & EGFR + & Carcinoma \\
\hline & SUM149 & CK $8+$, CK $18+$, CK $19+$ & Carcinoma \\
\hline & SUM159 & claudin low, CK $8+$, CK $18+$, CK $19+$ & Carcinoma \\
\hline
\end{tabular}

The correspondence between the cell lines and clinical features of the tumor of origin is provided. ${ }^{\text {a Estrogen }}$ receptors (ER), progesterone receptors (PR) and human epidermal growth factor receptor 2 (HER2) are all negative. Abbreviations: -, Negative; +, Positive; +++, Overexpression; ALDH, Aldehyde Dehydrogenase; CK, Cytokeratin; COX, Cyclooxygenase; EGF, Epidermal Growth Factor; EGFR, Epidermal Growth Factor Receptor; EGP, Epithelial Glycoprotein; EMA, Epithelial Membrane Antigen; EpCAM, Epithelial Cell Adhesion Molecule; ESA, Epithelial Specific Antigen; GFAP, Glial Fibrillary Acidic Protein; ICAM, Intercellular Adhesion Molecule; LHRH, Luteinizing Hormone-Releasing Hormone; N.A., Not Available; Ob-R, Leptin Receptor; PLK, Polo-Like Kinase; SMA, Smooth Muscle Actin; TGF alpha, Transforming growth factor alpha [4,10-13]. 
Besides their diagnostic use [14-21], metallodrugs or metal-based complexes (MBC) stand out for being promising chemotherapeutic agents [22]. The therapeutic potential of $\mathrm{MBC}$ has long been known; however, their role in the treatment of cancer is relatively recent (1960s). The first metal that laid the foundations of the modern era of metal-based anticancer drugs was platinum, and particularly its drug-derived cisplatin of which cytotoxic activity depends on apoptotic mechanisms and DNA repair defects caused by BRCA1 dysfunction [23,24], hence BRCA-deficient TNBC cells are particularly sensitive to it [25]. However, both cisplatin chemotherapies and its analogs have been shown to have major drawbacks (i.e., intrinsic and acquired chemoresistance, high general toxicity and limited spectrum of activity) [26] which have motivated extensive investigations into alternative metal-based cancer therapies that effectively target both cancer cell proliferation and metastasis. In this sense, we can mention chemotherapy with gold compounds [27-46] — because they are nontoxic, nonimmunogenic and have good photothermal and optical properties, biocompatibility and stability $[40,47,48]$ —and also with copper [49-51], ruthenium [16,52-59], iron [56,60-65], palladium [50], silver [66,67], iridium [68], osmium [68] and rhodium [69] compounds.

This paper aims to: (i) describe the preliminary in vitro and in vivo anticancer properties of non-platinum MBC (NPMBC) against TNBC; and (ii) analyze the likely molecular targets involved in their anticancer activity.

\section{Anticancer Effects of Non-Platinum MBC (NPMBC)}

The mechanisms behind the anticancer effects of NPMBC are not fully understood, but known responses to them include the following: (i) suppression of cancer cell viability (Table 2) in association with induction of cell death (Tables 3 and 4); and (ii) inhibition of metastatic processes (Table 5). Furthermore, a study suggests that NPMBC could also inhibit angiogenesis [55]; however, because of scarce evidence, no definitive conclusion can be drawn on the role of these compounds in the regulation of blood vessel formation. In any case, it is thought that NPMBC are frequently multi-targeted and attack different biochemical pathways simultaneously $[53,66,68]$, sometimes in a synergic way $[37,62]$. 
Table 2. Non-platinum metal based complexes (NPMBC) inhibit the in vitro and in vivo growth of triple-negative breast cancer (TNBC) cells by inhibiting tumor cell proliferation.

\begin{tabular}{|c|c|c|c|c|c|c|}
\hline \multicolumn{7}{|c|}{ In Vitro } \\
\hline Cell Line & NPMBC & Assay & $\begin{array}{c}\text { Mode of } \\
\text { Action/Pathway } \\
\text { Involved }\end{array}$ & Effect Observed & Doses Assayed & Reference \\
\hline MDA-MB-231 & $\begin{array}{l}\text { Multibranched gold } \\
\text { nanoantennas }\end{array}$ & Calcein/PI staining assay & - & Induction of cell death & $170 \mu \mathrm{g} / \mathrm{mL}$ & [14] \\
\hline $\begin{array}{l}\text { MDA-MB-231 } \\
\text { SUM159 } \\
\text { MDA-MB-468 } \\
\text { BT-549 }\end{array}$ & $\begin{array}{l}\text { Liposome encapsulated } \\
\text { ruthenium polypyridine } \\
\text { complex }\end{array}$ & MTT assay & - & Reduced cell viability & $<4 \mu \mathrm{M}$ & [16] \\
\hline MDA-MB-231 & $\begin{array}{l}\text { Liposome encapsulated } \\
\text { ruthenium polypyridine } \\
\text { complex }\end{array}$ & $\begin{array}{l}\text { Western blot } \\
\text { Immunofluorescence }\end{array}$ & $\begin{array}{l}\gamma-\mathrm{H} 2 \mathrm{AX} \\
\text { ATM }\end{array}$ & $\begin{array}{c}\text { Increased levels of } \gamma \text {-H2AX } \\
\text { Degradation and dephosphorylation } \\
\text { of ATM }\end{array}$ & $3 \mu \mathrm{M}$ & [16] \\
\hline MDA-MB-231 & $\begin{array}{l}\text { Gold nanostars loaded with } \\
\text { AS1411 }\end{array}$ & $\begin{array}{l}\text { Resazurin cell viability } \\
\text { assay }\end{array}$ & - & $40 \%$ cell viability & $0.3 \mathrm{nM}$ & {$[27]$} \\
\hline MDA-MB-231 & $\begin{array}{l}\text { CD44-targeting HSP72 depletion } \\
\text { nanosystem based on plasmonic } \\
\text { gold nanoparticles }\end{array}$ & MTT assay & - & $20-85 \%$ cell death & $50 \mathrm{mg} / \mathrm{L}$ & [28] \\
\hline MDA-MB-231 & $\begin{array}{l}\text { Multibranched gold } \\
\text { nanoantennas }\end{array}$ & MTT assay & - & $\sim 40 \%$ cell viability & $170 \mu \mathrm{g} / \mathrm{mL}$ & [29] \\
\hline MDA-MB-231 & Gold nanoparticles & MTT assay & - & $15-75 \%$ survival & $0.1-100 \mu \mathrm{M}$ & [31] \\
\hline MDA-MB-231 & $\begin{array}{l}\text { Thioglucose-bound gold } \\
\text { nanoparticles }\end{array}$ & MTT assay & - & Inhibited cell growth & $20 \mathrm{nM}$ & {$[36]$} \\
\hline MDA-MB-231 & $\begin{array}{l}\text { Thioglucose-bound gold } \\
\text { nanoparticles }\end{array}$ & $\begin{array}{l}\text { Clonogenic cell survival } \\
\text { assay }\end{array}$ & - & Enhanced radiosensitivity & $20 \mathrm{nM}$ & [36] \\
\hline $\begin{array}{l}\text { MDA-MB-231 } \\
\text { MDA-MB-468 }\end{array}$ & $\begin{array}{l}\text { Anti-EGFR-gold nanorod } \\
\text { conjugates }\end{array}$ & MTT assay & - & Inhibited cell growth & $1.84 \mu \mathrm{g} / \mathrm{mL}$ & {$[37]$} \\
\hline MDA-MB-231 & $\begin{array}{l}\text { Anti-EGFR-gold nanorod } \\
\text { conjugates }\end{array}$ & Western blot & $\begin{array}{c}\text { Ki-67 } \\
\text { EGFR } \\
\text { Akt } \\
\text { ERK1/2 } \\
\text { mTOR } \\
\text { FAK }\end{array}$ & $\begin{array}{l}\text { Decreased Ki-67 and EGFR expression } \\
\text { Suppression of phosphorylation of } \\
\text { FAK, ERK1/2, mTOR and Akt }\end{array}$ & $1.84 \mu \mathrm{g} / \mathrm{mL}$ & [37] \\
\hline MDA-MB-231 & $\begin{array}{l}\text { Anti-EGFR-gold nanorod } \\
\text { conjugates }\end{array}$ & CCK-8 assay & - & $32.2 \%$ cell viability & $120 \mathrm{pM}$ & [38] \\
\hline MDA-MB-231 & $\begin{array}{l}\text { Gold nanospheres conjugated } \\
\text { with AS1411 }\end{array}$ & MTT assay & - & Inhibited cell viability & $<100 \mathrm{nM}$ & [39] \\
\hline $\begin{array}{l}\text { MDA-MB-231 } \\
\text { SUM1315 } \\
\text { HCC1937 } \\
\text { MDA-MB-468 }\end{array}$ & $\begin{array}{l}\text { Gold-nanoparticles conjugated } \\
\text { with Rad6 inhibitor }\end{array}$ & $\begin{array}{c}\text { MTT assay } \\
\text { Trypan blue staining assay }\end{array}$ & - & $\begin{array}{l}\text { Decreased cell viability (SUM1315 and } \\
\text { MDA-MB-231) } \\
\text { No change in viability of HCC1937 and } \\
\text { MDA-MB-468 }\end{array}$ & $\begin{array}{l}0.5 \mu \mathrm{M} \text { for SUM1315; } \\
8.2 \mu \mathrm{M} \text { for MDA-MB-231 }\end{array}$ & [40] \\
\hline
\end{tabular}


Table 2. Cont

\begin{tabular}{|c|c|c|c|c|c|c|}
\hline \multicolumn{7}{|c|}{ In Vitro } \\
\hline Cell Line & NPMBC & Assay & $\begin{array}{c}\text { Mode of } \\
\text { Action/Pathway } \\
\text { Involved }\end{array}$ & Effect Observed & Doses Assayed & Reference \\
\hline MDA-MB-231 & $\begin{array}{l}\text { Gold nanoparticles loaded with } \\
\text { 5-fluorouracil }\end{array}$ & MTT assay & - & Decreased cell viability & $0.5 \mathrm{nM}$ & [41] \\
\hline MDA-MB-231 & Chitosan layered gold nanorods & $\begin{array}{l}\text { MTS-based colorimetric } \\
\text { assay }\end{array}$ & - & $\sim 65 \%$ inhibition of cell proliferation & $100 \mathrm{nM}$ & [43] \\
\hline $\begin{array}{l}\text { MDA-MB-231 } \\
\text { MDA-MB-468 }\end{array}$ & $\begin{array}{l}\text { Micellar gold nanoparticles } \\
\text { conjugated with ZD6474 }\end{array}$ & MTT assay & - & $\begin{array}{l}\text { 80.51\% (MDA-MB-231) and } \sim 92 \% \\
\text { (MDA-MB-468) inhibition of cell } \\
\text { proliferation }\end{array}$ & $1-10 \mu \mathrm{M}$ & [44] \\
\hline $\begin{array}{l}\text { MDA-MB-231 } \\
\text { BT-20 }\end{array}$ & $\begin{array}{c}\text { Copper salicylate } \\
\text { phenanthroline complexes }\end{array}$ & $\begin{array}{l}\text { MTS-based colorimetric } \\
\text { assay }\end{array}$ & - & Inhibition of cell growth & $5-25 \mu \mathrm{M}$ & [49] \\
\hline MDA-MB-231 & $\begin{array}{l}\text { Copper complexes of } \\
\text { phenanthrenequinone } \\
\text { thiosemicarbazone }\end{array}$ & MTT assay & - & Decreased cell viability & $2.3-4.8 \mu \mathrm{M}$ & [50] \\
\hline MDA-MB-231 & $\begin{array}{l}\text { Nickel complexes of } \\
\text { phenanthrenequinone } \\
\text { thiosemicarbazone }\end{array}$ & MTT assay & - & Decreased cell viability & $>10 \mu \mathrm{M}$ & [50] \\
\hline MDA-MB-231 & $\begin{array}{l}\text { Palladium complexes of } \\
\text { phenanthrenequinone } \\
\text { thiosemicarbazone }\end{array}$ & MTT assay & - & Decreased cell viability & $>10 \mu \mathrm{M}$ & [50] \\
\hline MDA-MB-231 & $\begin{array}{l}\text { Copper oxide nanowire } \\
\text { conjugated with folic acid }\end{array}$ & Flow cytometry & - & $60 \%$ cell death & $2.5 \mu \mathrm{g} / \mathrm{mL}$ & [51] \\
\hline MDA-MB-231 & $\begin{array}{l}\text { Water-soluble } \\
\text { iminophosphorane } \\
\text { ruthenium(II) compounds }\end{array}$ & MTT assay & - & Decreased cell viability & $2.61-75.4 \mu \mathrm{M}$ & [52] \\
\hline $\begin{array}{l}\text { MDA-MB-231 } \\
\text { MDA-MB-468 } \\
\text { MDA-MB-436 }\end{array}$ & $\begin{array}{l}\text { Ruthenium-based nucleolipidic } \\
\text { nanoaggregates }\end{array}$ & $\begin{array}{l}\text { MTT assay } \\
\text { Trypan blue }\end{array}$ & - & Reduced cell proliferation & $12.1-14.7 \mu \mathrm{M}$ & [53] \\
\hline $\begin{array}{l}\text { MDA-MB-231 } \\
\text { HCC1937 }\end{array}$ & Ruthenium complexes & $\begin{array}{l}\text { Real-time cell growth } \\
\text { profiling } \\
\text { MTT assay }\end{array}$ & - & Inhibited cell viability & $\begin{array}{l}13.2 \text { and } 14.1 \mu \mathrm{M} \text { for } \\
\text { MDA-MB-231; } 1.8 \text { and } \\
9.9 \mu \mathrm{M} \text { for HCC1937 }\end{array}$ & [54] \\
\hline $\begin{array}{c}\text { A17 } \\
\text { MDA-MB-231 }\end{array}$ & Ruthenium complexes & MTT assay & - & Inhibited cell viability & $\begin{array}{l}230.66 \mu \mathrm{M} \text { for A17; } \\
409.89 \mu \mathrm{M} \text { for } \\
\text { MDA-MB-231 }\end{array}$ & [55] \\
\hline MDA-MB-231 & $\begin{array}{l}\text { Ansa-ferrocenes } \\
\text { ruthenocenophanes }\end{array}$ & MTT assay & - & Decreased cell viability & $0.09-4.53 \mu \mathrm{M}$ & [56] \\
\hline MDA-MB-231 & $\begin{array}{l}\text { Ruthenium(II) paracyme } \\
\text { complexes }\end{array}$ & Sulforhodamine B assay & - & Decreased cell viability & $9.2-29.1 \mu \mathrm{M}$ & [57] \\
\hline MDA-MB-231 & Ruthenium complexes & MTT assay & - & Decreased cell viability & $8.81-21.92 \mu \mathrm{M}$ & [58] \\
\hline MDA-MB-231 & Ruthenium complexes & Colony formation & - & $100 \%$ inhibition of the colony formation & $2 \mu \mathrm{M}$ & [58] \\
\hline MDA-MB-231 & Ruthenium-based compounds & MTT assay & - & Decreased cell viability & 31.16 and $52.74 \mu \mathrm{M}$ & [59] \\
\hline
\end{tabular}


Table 2. Cont

\begin{tabular}{|c|c|c|c|c|c|c|}
\hline \multicolumn{7}{|c|}{ In Vitro } \\
\hline Cell Line & NPMBC & Assay & $\begin{array}{l}\text { Mode of } \\
\text { Action/Pathway } \\
\text { Involved }\end{array}$ & Effect Observed & Doses Assayed & Reference \\
\hline MDA-MB-231 & Ruthenium-based compounds & Colony formation & - & $100 \%$ inhibition of the colony formation & $20 \mu \mathrm{M}$ & [59] \\
\hline SUM159 & Iron oxide nanoparticles & $\begin{array}{l}\text { Alamar blue cell viability } \\
\text { assay } \\
\text { Flow cytometry }\end{array}$ & - & $5-80 \%$ cell viability & $10 \mu \mathrm{M}$ & [61] \\
\hline MDA-MB-231 & $\begin{array}{l}\text { Supermagnetic iron oxide } \\
\text { nanoparticles conjugated with } \\
\text { doxorubicin }\end{array}$ & $\begin{array}{l}\text { MTS-based colorimetric } \\
\text { assay }\end{array}$ & - & $31 \%$-cell viability & $520 \mu \mathrm{M}$ & [62] \\
\hline MDA-MB-231 & $\begin{array}{l}\text { Chitosan hydrogel cross-linked } \\
\text { with telechelic difunctional } \\
\text { poly(ethylene glycol) modified } \\
\text { iron oxide magnetic } \\
\text { nanoparticles }\end{array}$ & CCK-8 assay & - & $5.6 \%$ cell viability & $10.8-35.8 \mu \mathrm{M}$ & [63] \\
\hline $\begin{array}{l}\text { MDA-MB-231 } \\
\text { HCC1806 }\end{array}$ & $\begin{array}{l}\text { Iron oxide nanoparticles linked } \\
\text { antagonist for leptin }\end{array}$ & MTT assay & - & $\begin{array}{l}\text { Prevention of leptin-induced cell } \\
\text { proliferation }\end{array}$ & $0.0036 \mathrm{pmol} / \mathrm{L}$ & [64] \\
\hline $\begin{array}{l}\text { MDA-MB-231 } \\
\text { HCC1806 }\end{array}$ & $\begin{array}{l}\text { Iron oxide nanoparticles linked } \\
\text { antagonist for leptin }\end{array}$ & Immunoblotting analysis & Cyclin D1 & $\begin{array}{l}\text { Prevention of leptin-induced cyclin D1 } \\
\text { expression }\end{array}$ & $0.0036 \mathrm{pmol} / \mathrm{L}$ & [64] \\
\hline $\begin{array}{l}\text { MDA-MB-231 } \\
\text { HCC1806 }\end{array}$ & $\begin{array}{l}\text { Iron oxide nanoparticles linked } \\
\text { antagonist for leptin }\end{array}$ & Cell cycle analysis & - & $\begin{array}{l}\text { Prevention of leptin-induced cell cycle } \\
\text { progression }\end{array}$ & $\begin{array}{c}0.0018-0.0036 \mathrm{pmol} / \mathrm{L} \text { for } \\
\text { MDA-MB-231 and } \\
0.0018-0.036 \mathrm{pmol} / \mathrm{L} \text { for } \\
\text { HCC1806 }\end{array}$ & [64] \\
\hline $\begin{array}{l}\text { MDA-MB-231 } \\
\text { HCC } 1806\end{array}$ & $\begin{array}{c}\text { Iron oxide nanoparticles linked } \\
\text { antagonist for leptin }\end{array}$ & $\begin{array}{l}\text { FITC-annexin V/PI staining } \\
\text { assay }\end{array}$ & - & Decreased cell viability & $0.0036 \mathrm{pmol} / \mathrm{L}$ & [64] \\
\hline MDA-MB-231 & $\begin{array}{l}\text { Doxorubicin-hyaluronan } \\
\text { conjugated iron oxide } \\
\text { nanoparticles }\end{array}$ & Confocal microscopy & Vimentin e-cadherin & $\begin{array}{l}\text { Decreased vimentin expression } \\
\text { No change in e-cadherin expression }\end{array}$ & $2 \mu \mathrm{M}$ & [65] \\
\hline $\begin{array}{l}\text { MDA-MB-231 } \\
\text { BT549 } \\
\text { SUM-159 }\end{array}$ & Silver nanoparticles & MTT assay & - & Inhibited cell viability & $\geq 10 \mu \mathrm{g} / \mathrm{mL}$ & [66] \\
\hline $\begin{array}{l}\text { MDA-MB-231 } \\
\text { BT549 } \\
\text { SUM-159 }\end{array}$ & Silver nanoparticles & Clonogenic assay & - & $100 \%$ inhibition of clonogenic growth & $\geq 10 \mu \mathrm{g} / \mathrm{mL}$ & [66] \\
\hline MDA-MB-231 & Silver nanoparticles & MTT assay & - & Decreased cell viability & $\begin{array}{l}6.72 \mu \mathrm{g} / \mathrm{mL} \text { at } 12 \mathrm{~h} \text { and } \\
2.62 \mu \mathrm{g} / \mathrm{mL} \text { at } 24 \mathrm{~h}\end{array}$ & [67] \\
\hline $\begin{array}{l}\text { MDA-MB-468 } \\
\text { OCUB-M }\end{array}$ & $\begin{array}{l}\text { Organo-iridium complexes } \\
\text { Organo-osmium complexes }\end{array}$ & MTT assay & - & Decreased cell viability & $<1 \mu \mathrm{M}$ & [68] \\
\hline $\begin{array}{l}\text { MDA-MB-468 } \\
\text { MDA-MB-231 }\end{array}$ & Rhodium(III) complex & MTT assay & - & Inhibited cell proliferation & 0.35 and $0.55 \mu \mathrm{M}$ & [69] \\
\hline
\end{tabular}


Table 2. Cont.

\begin{tabular}{|c|c|c|c|c|c|c|}
\hline \multicolumn{7}{|c|}{ In Vitro } \\
\hline Cell Line & NPMBC & Assay & $\begin{array}{l}\text { Mode of } \\
\text { Action/Pathway } \\
\text { Involved }\end{array}$ & Effect Observed & Doses Assayed & Reference \\
\hline MDA-MB-231 & Rhodium(III) complex & Western blot & $\begin{array}{c}\text { Wee } 1 \\
\text { Cdc2 } \\
\text { ERK } \\
\text { Akt } \\
\text { Cyclin A2 } \\
\gamma \text {-H2AX }\end{array}$ & $\begin{array}{c}\text { Decreased phosphorylation of ERK, } \\
\text { Akt, Cdc2 } \\
\text { Decreased expression of cyclin A2 } \\
\text { Increased } \gamma \text {-H2AX } \\
\text { levels } \\
\text { Inhibition of Wee1 activity }\end{array}$ & $1-3 \mu \mathrm{M}$ & [69] \\
\hline \multicolumn{7}{|c|}{ In Vivo } \\
\hline Cell Line & NPMBC & $\begin{array}{l}\text { Animal (Model)/Analysis } \\
\text { from Animal Tissue }\end{array}$ & $\begin{array}{l}\text { Mode of } \\
\text { Action/Pathway } \\
\text { Involved }\end{array}$ & Effect Observed & $\begin{array}{l}\text { Doses Assayed (Route of } \\
\text { Administration) }\end{array}$ & Reference \\
\hline MDA-MB-231 & $\begin{array}{l}\text { Liposome encapsulated } \\
\text { ruthenium polypyridine } \\
\text { complex }\end{array}$ & $\begin{array}{l}\text { Athymic nude mice } \\
\text { (orthotopic)/Immunofluorescen } \\
\text { imaging }\end{array}$ & Ki-67 & Decreased Ki-67 level & $5 \mathrm{mg}$ ruthenium $/ \mathrm{kg}$ (i.v.) & [16] \\
\hline MDA-MB-231 & $\begin{array}{l}\text { Liposome encapsulated } \\
\text { ruthenium polypyridine } \\
\text { complex }\end{array}$ & $\begin{array}{l}\text { Athymic nude mice } \\
\text { (orthotopic) }\end{array}$ & - & $\begin{array}{l}\text { Suppression of tumor growth (tumor } \\
\text { weights: } 0.342 \text { with nanoparticles vs. } \\
0.992 \text { with control) }\end{array}$ & $5 \mathrm{mg}$ ruthenium $/ \mathrm{kg}$ (i.v.) & [16] \\
\hline MDA-MB-231 & $\begin{array}{l}\text { CD44-targeting HSP72 depletion } \\
\text { nanosystem based on plasmonic } \\
\text { gold nanoparticles }\end{array}$ & Nude mice (xenograft) & - & Smaller tumor volume than control & $10 \mathrm{mg} / \mathrm{kg}$ (i.v.) & [28] \\
\hline MDA-MB-231 & $\begin{array}{l}\text { Gold nanomatryoshkas and } \\
\text { nanoshells }\end{array}$ & $\begin{array}{l}\text { Sprague-Dawley athymic } \\
\text { nude mice (xenograft) }\end{array}$ & - & $\begin{array}{c}\text { Improved survival (15.8 and } 11.3 \text { days } \\
\text { with nanomatryoshkas and nanoshells } \\
\text { respectively) } \\
\text { Slower tumor growth with } \\
\text { nanomatryoshkas }\end{array}$ & $300 \mu \mathrm{g}$ of gold (i.v.) & [32] \\
\hline MDA-MB-231 & $\begin{array}{l}\text { Anti-EGFR-gold nanorod } \\
\text { conjugates }\end{array}$ & $\begin{array}{l}\text { BALB/c nude mice } \\
\text { (xenograft) }\end{array}$ & - & $\begin{array}{l}\text { Smaller tumor volumen than control } \\
\text { ( < <50 vs. } 250 \mathrm{~mm}^{3} \text { respectively) }\end{array}$ & $0.5 \mathrm{pmol} / \mathrm{g}$ mouse (i.v.) & {$[37]$} \\
\hline MDA-MB-231 & $\begin{array}{l}\text { Anti-EGFR-gold nanorod } \\
\text { conjugates }\end{array}$ & $\begin{array}{c}\text { BALB/c nude mice } \\
\text { (xenograft)/Immunohistochemistry }\end{array}$ & $\begin{array}{l}\text { Ki-67 } \\
\text { EGFR }\end{array}$ & Decreased Ki-67 and EGFR levels & $0.5 \mathrm{pmol} / \mathrm{g}$ mouse (i.v.) & [37] \\
\hline MDA-MB-231 & $\begin{array}{l}\text { Gold nanospheres conjugated } \\
\text { with AS1411 }\end{array}$ & $\begin{array}{l}\text { Nude mice Fox } 1^{\text {nu }} \\
\text { (xenograft) }\end{array}$ & - & $\begin{array}{l}\text { Decreased tumor grow rate and tumor } \\
\text { regression (tumor size at } 12 \text { days: } 100 \\
\text { with nanospheres vs. } 1000 \mathrm{~mm}^{3} \text { with } \\
\text { control) }\end{array}$ & $1 \mathrm{mg} / \mathrm{kg} /$ day (i.p.) & [39] \\
\hline MDA-MB-231 & $\begin{array}{l}\text { Hydrogel embedded with gold } \\
\text { nanoparticles }\end{array}$ & $\begin{array}{l}\text { SCID hairless congenic } \\
\text { mice (orthotopic) }\end{array}$ & - & $\begin{array}{l}\text { Efficient and sustained inhibition of } \\
\text { tumor growth ( } \sim 90 \% \text { tumor size } \\
\text { reduction) }\end{array}$ & $\begin{array}{c}10 \mathrm{nM} \text { of gold } \\
\text { nanoparticles (i.h.) }\end{array}$ & [41] \\
\hline MDA-MB-231 & $\begin{array}{c}\text { Gold nanomatryoshkas and } \\
\text { nanoshells }\end{array}$ & $\begin{array}{l}\text { Sprague-Dawley athymic } \\
\text { nude mice (xenograft) }\end{array}$ & - & $\begin{array}{l}\text { Improved survival ( } 83 \% \text { and } 33 \% \text { at } \\
60 \text { days with nanomatryoshkas and } \\
\text { nanoshells respectively) } \\
\text { Complete tumor regression at } 60 \text { days } \\
\text { post-treatment with relapse rates } \\
\text { between } 16.7 \% \text { (nanomatryoshkas) and } \\
50 \% \text { (nanoshells) }\end{array}$ & $300 \mu \mathrm{g}$ of gold (i.v.) & [42] \\
\hline
\end{tabular}


Table 2. Cont.

\begin{tabular}{|c|c|c|c|c|c|c|}
\hline \multicolumn{7}{|c|}{ In Vitro } \\
\hline Cell Line & NPMBC & Assay & $\begin{array}{l}\text { Mode of } \\
\text { Action/Pathway } \\
\text { Involved }\end{array}$ & Effect Observed & Doses Assayed & Reference \\
\hline MDA-MB-231 & $\begin{array}{l}\text { Micellar gold nanoparticles } \\
\text { conjugated with ZD } 6474\end{array}$ & $\begin{array}{c}\text { Athymic BALB/c } \\
(\mathrm{nu}+/ \text { /nu+) mice (xenograft) }\end{array}$ & - & $\begin{array}{c}\text { Decrease in tumor volume (63\% of } \\
\text { control) }\end{array}$ & $\begin{array}{l}30 \mathrm{mg} / \mathrm{kg} \text { of ZDD6474 } \\
\text { (i.v.) }\end{array}$ & [44] \\
\hline BCM-2665A & Gold nanoshells & $\begin{array}{l}\text { SCID/beige mice } \\
\text { (xenograft) }\end{array}$ & - & $\begin{array}{l}\text { Smaller tumor volume compared to } \\
\text { control ( } 400 \mathrm{vs} .800 \mathrm{~mm}^{3} \text { respectively) }\end{array}$ & $\begin{array}{c}\sim 8 \times 10^{8} \text { nanoshells } / g \\
\text { body weight (i.v.) }\end{array}$ & [45] \\
\hline MDA-MB-231 & $\begin{array}{l}\text { RGD-conjugated mesoporous } \\
\text { silica-encapsulated gold } \\
\text { nanorods }\end{array}$ & Nude mice (orthotopic) & - & $\begin{array}{l}\text { Smaller tumor volume than control } \\
\text { (569 vs. } 1302 \mathrm{~mm}^{3} \text { respectively) }\end{array}$ & $\begin{array}{l}\sim 50 \mu \mathrm{g} \text { of gold } / \mathrm{g} \text { of } \\
\text { body weight (i.v.) }\end{array}$ & [46] \\
\hline MDA-MB-231 & $\begin{array}{c}\text { Copper salicylate } \\
\text { phenanthroline complexes }\end{array}$ & Nude mice (xenograft) & - & $\begin{array}{l}\text { Smaller tumor volume than control ( } 20 \\
\text { vs. } 35 \mathrm{~mm}^{3} \text { respectively) }\end{array}$ & 0.5 mg/mL (i.p.) & [49] \\
\hline MDA-MB-231 & $\begin{array}{l}\text { Copper salicylate } \\
\text { phenanthroline complexes }\end{array}$ & $\begin{array}{l}\text { Nude mice } \\
\text { (xenograft)/Immunohistochemical } \\
\text { staining }\end{array}$ & Ki-67 & Reduced Ki-67 expression & 0.5 mg/mL (i.p.) & [49] \\
\hline MDA-MB-231 & $\begin{array}{l}\text { Water-soluble } \\
\text { iminophosphorane } \\
\text { ruthenium(II) compounds }\end{array}$ & $\begin{array}{l}\text { NOD.CB17-Prkdc SCID/J } \\
\text { mice (xenograft) }\end{array}$ & - & $\begin{array}{l}\text { Significant inhibition of tumor growth } \\
\text { and smaller tumor size than control } \\
\text { (56\% decrease vs. } 200 \% \text { increase in } \\
\text { tumor volume respectively) }\end{array}$ & 5 mg/kg/day (i.p.) & [52] \\
\hline A17 & Ruthenium complexes & FVB/NCrl mice (xenograft) & - & $\begin{array}{l}\text { Decreased tumor grow rate and smaller } \\
\text { tumor size than control }(<3 \mathrm{vs} .7 \mathrm{~mm})\end{array}$ & 210 mg/kg/day (i.p.) & [55] \\
\hline SUM159 & $\begin{array}{l}\text { Highly crystallized iron oxide } \\
\text { nanoparticles }\end{array}$ & $\begin{array}{l}\text { BALB/c } \\
\text { immune-competent mice } \\
\text { (xenograft) }\end{array}$ & - & $\begin{array}{l}\text { Complete tumor regression without } \\
\text { relapses }\end{array}$ & $\begin{array}{l}20 \mathrm{mg} \text { iron } / \mathrm{kg} \text { body } \\
\text { weight (i.v.) }\end{array}$ & [60] \\
\hline SUM159 & Iron oxide nanoparticles & $\begin{array}{l}\text { NOD/SCID } \\
\text { immune-compromised } \\
\text { mice (orthotopic) }\end{array}$ & - & Smaller tumor size than control & $\begin{array}{l}20 \mathrm{mg} \text { iron } / \mathrm{kg} \text { body } \\
\text { weight (i.v.) }\end{array}$ & [61] \\
\hline $4 \mathrm{~T} 1$ & $\begin{array}{l}\text { Supermagnetic iron oxide } \\
\text { nanoparticles conjugated with } \\
\text { doxorubicin }\end{array}$ & BALB/c mice (orthotopic) & - & $\begin{array}{l}\text { Smaller tumor size than control (7 vs. } \\
\qquad 74 \mathrm{~mm}^{3} \text { respectively) }\end{array}$ & $\underset{\text { (i.t.) }}{0.25 \mathrm{mg} \text { iron } / 100 \mathrm{~mm}^{3}}$ & [62] \\
\hline MDA-MB-231 & $\begin{array}{l}\text { Chitosan hydrogel cross-linked } \\
\text { with telechelic difunctional } \\
\text { poly(ethylene glycol) modified } \\
\text { iron oxide magnetic } \\
\text { nanoparticles }\end{array}$ & BALB/c mice (xenograft) & - & $\begin{array}{l}\text { Smaller tumor size than control } \\
\text { (relative tumor volume } \sim 0.75 \text { vs. } 4.5 \\
v / v \text { respectively) }\end{array}$ & $18.7 \mathrm{mg} / \mathrm{kg}$ (i.t.) & [63] \\
\hline MDA-MB-231 & Silver nanoparticles & $\begin{array}{l}\text { nu/nu athymic mice } \\
\text { (xenograft) }\end{array}$ & - & $\begin{array}{l}\text { Decreased tumor grow rate and smaller } \\
\text { tumor size than control (250 vs. } 550 \\
\mathrm{~mm}^{3} \text { respectively) }\end{array}$ & $\begin{array}{l}0.2 \mu \mathrm{gg} / \mathrm{mm}^{3} \text { tumor } \\
\text { volume (i.t.) }\end{array}$ & [66] \\
\hline MDA-MB-231 & $\begin{array}{l}\text { Gold nanorod-loaded neural } \\
\text { stem cells }\end{array}$ & $\begin{array}{l}\text { Athymic nude mice } \\
\text { (xenograft) }\end{array}$ & - & $\begin{array}{l}\text { Complete tumor ablation, improved } \\
\text { survival and reduced tumor recurrence } \\
\text { compared to control }\end{array}$ & $12.5 \mu \mathrm{g} /$ (i.t.) & [70] \\
\hline
\end{tabular}

Abbreviations: - , Not analyzed; Akt, Protein Kinase B; ATM, Ataxia Telangiectasia Mutated Protein; CCK-8, Cell Counting Kit-8; Cdc2, Cell Division Control Protein 2

Homolog; EGFR, Epidermal Growth Factor Receptor; ERK, Extracellular Signal-Regulated Kinase; FAK, Focal Adhesion Kinase; Fox 1, Forkhead Box Protein 1; HSP72, Heat Shock Protein 72; i.h., implantation of a hydrogel disk on top of the tumors; i.p., intraperitoneal injection; i.t., intratumoral injection; i.v., intravenous injection; MRP1, Multidrug Resistance Protein 1; mTOR, Mammalian Target of Rapamycin; MTS, 3-(4,5-Dimethylthiazol-2-yl)-5-(3-Carboxymethoxyphenyl)-2(4-Sulfonyl)-2H-Tetrazolium; MTT, 3-(4,5-Dimethylthiazol-2-yl)-2,5-Diphenyltetrazolium Bromide; NOD, Non-Obese Diabetic; PI, Propidium Iodide; SCID, Severe Combined Immunodeficient. 
Table 3. Non-platinum metal based complexes (NPMBC) inhibit the in vitro and in vivo growth of triple-negative breast cancer (TNBC) cells by inducing apoptosis.

\begin{tabular}{|c|c|c|c|c|c|c|}
\hline \multicolumn{7}{|c|}{ In Vitro } \\
\hline Cell Line & NPMBC & Assay & $\begin{array}{c}\text { Mode of } \\
\text { Action/Pathway } \\
\text { Involved }\end{array}$ & Effect Observed & Doses Assayed & Reference \\
\hline MDA-MB-231 & $\begin{array}{l}\text { Liposome encapsulated ruthenium } \\
\text { polypyridine complex }\end{array}$ & Western blot & $\begin{array}{c}\text { PARP } \\
\text { Caspase } 3 \\
\text { Caspase } 8 \\
\text { Caspase } 9\end{array}$ & $\begin{array}{l}\text { Increased cleaved PARP, caspase } 3, \\
\text { caspase } 8 \text { and caspase } 9 \text { levels }\end{array}$ & $5 \mu \mathrm{M}$ & [16] \\
\hline MDA-MB-231 & $\begin{array}{l}\text { Liposome encapsulated ruthenium } \\
\text { polypyridine complex }\end{array}$ & $\begin{array}{c}\text { Flow cytometry (cell cycle } \\
\text { arrest) }\end{array}$ & - & $\begin{array}{c}75.9 \% \text { apoptotic cells } \\
54 \% \text { cells in the G2/M phase }\end{array}$ & $5 \mu \mathrm{M}$ & [16] \\
\hline MDA-MB-231 & Gold nanostars & $\begin{array}{l}\text { Fluorescent assay } \\
\text { qPCR }\end{array}$ & $\begin{array}{c}\text { Caspase } 3 / 7 \\
\text { Bcl-2 }\end{array}$ & $\begin{array}{c}\text { Increased caspase activity } \\
\text { Downregulation of Bcl-2 expression }\end{array}$ & $0.3 \mathrm{nM}$ & [27] \\
\hline MDA-MB-231 & Multibranched gold nanoantennas & $\begin{array}{c}\text { Annexin } V / \text { calcein/PI staining } \\
\text { assay }\end{array}$ & - & Induction of apoptotic cell death & $170 \mu \mathrm{g} / \mathrm{mL}$ & [29] \\
\hline MDA-MB-231 & $\begin{array}{l}\text { Gold nanoparticles conjugated } \\
\text { gemcitabine }\end{array}$ & Annexin V/7-AAD assay & - & Induction of apoptosis & $0.5,1,5,25 \mathrm{nM}$ & [30] \\
\hline MDA-MB-231 & Anti-EGFR-gold nanorod conjugates & $\begin{array}{l}\text { FITC-annexin V/PI staining } \\
\text { assay }\end{array}$ & - & $\sim 25-40 \%$ apoptotic cells & $1.84 \mu \mathrm{g} / \mathrm{mL}$ & [37] \\
\hline MDA-MB-231 & Anti-EGFR-gold nanorod conjugates & Western blot & Caspase 3 & Increased cleaved caspase 3 protein & $1.84 \mu \mathrm{g} / \mathrm{mL}$ & [37] \\
\hline MDA-MB-231 & Gold nanospheres & $\begin{array}{l}\text { FITC-annexin V/PI staining } \\
\text { assay }\end{array}$ & - & $88 \%$ apoptotic cells & $200 \mathrm{nM}$ & [39] \\
\hline $\begin{array}{l}\text { MDA-MB-231 } \\
\text { SUM1315 } \\
\text { HCC1937 } \\
\text { MDA-MB-468 }\end{array}$ & $\begin{array}{l}\text { Gold-nanoparticles conjugated with } \\
\text { Rad6 inhibitor }\end{array}$ & $\begin{array}{l}\text { Acridine orange/ethidium } \\
\text { bromide staining }\end{array}$ & - & $\begin{array}{l}\text { SUM1315 and MDA-MB-231 cells in early } \\
\text { and late stages of apoptosis } \\
\text { No morphological alterations consistent } \\
\text { with apoptosis were observed in } \\
\text { HCC1937 or MDA-MB-468 cells }\end{array}$ & $1-5 \mu \mathrm{M}$ & [40] \\
\hline $\begin{array}{l}\text { SUM1315 } \\
\text { HCC1937 }\end{array}$ & $\begin{array}{l}\text { Gold-nanoparticles conjugated with } \\
\text { Rad6 inhibitor }\end{array}$ & $\begin{array}{l}\text { Mitochondrial membrane } \\
\text { potential (JC-1) }\end{array}$ & - & $\begin{array}{c}\text { Loss in the mitochondrial function } \\
\text { of SUM1315 cells } \\
\text { Mitochondrial function of HCC1937 cells } \\
\text { was unaffected }\end{array}$ & $1 \mu \mathrm{M}$ & [40] \\
\hline $\begin{array}{l}\text { SUM1315 } \\
\text { HCC1937 }\end{array}$ & $\begin{array}{l}\text { Gold-nanoparticles conjugated with } \\
\text { Rad6 inhibitor }\end{array}$ & Western blot & PARP-1 & Activation of PARP-1 & $1-5 \mu \mathrm{M}$ & [40] \\
\hline MDA-MB-468 & $\begin{array}{l}\text { Micellar gold nanoparticles } \\
\text { conjugated with ZD6474 }\end{array}$ & $\begin{array}{l}\text { FITC-annexin V/PI staining } \\
\text { assay }\end{array}$ & - & $28.2 \%$ apoptotic cells & $5 \mu \mathrm{M}$ & [44] \\
\hline MDA-MB-231 & $\begin{array}{l}\text { RGD-conjugated mesoporous } \\
\text { silica-encapsulated gold nanorods }\end{array}$ & $\begin{array}{l}\text { FITC-annexin V/PI staining } \\
\text { assay }\end{array}$ & - & Increased apoptotic cells & $50 \mu \mathrm{g} / \mathrm{mL}$ & [46] \\
\hline MDA-MB-231 & $\begin{array}{l}\text { RGD-conjugated mesoporous } \\
\text { silica-encapsulated gold nanorods }\end{array}$ & DHE fluorescence method & ROS & Increased cellular ROS levels & $50 \mu \mathrm{g} / \mathrm{mL}$ & [46] \\
\hline $\begin{array}{l}\text { MDA-MB-231 } \\
\text { BT-20 }\end{array}$ & $\begin{array}{l}\text { Copper salicylate phenanthroline } \\
\text { complexes }\end{array}$ & Flow cytometry (Annexin V/PI) & - & $>80 \%$ apoptotic cells & $25 \mu \mathrm{M}$ & [49] \\
\hline
\end{tabular}


Table 3. Cont

\begin{tabular}{|c|c|c|c|c|c|c|}
\hline \multicolumn{7}{|c|}{ In Vitro } \\
\hline Cell Line & NPMBC & Assay & $\begin{array}{l}\text { Mode of } \\
\text { Action/Pathway } \\
\text { Involved }\end{array}$ & Effect Observed & Doses Assayed & Reference \\
\hline $\begin{array}{l}\text { MDA-MB-231 } \\
\text { BT-20 }\end{array}$ & $\begin{array}{l}\text { Copper salicylate phenanthroline } \\
\text { complexes }\end{array}$ & Western blot & $\begin{array}{c}\text { Bcl-2 } \\
\text { Bcl-xL } \\
\text { Survivin } \\
\text { PARP } \\
\end{array}$ & $\begin{array}{l}\text { Decreased Bcl-2, Bcl-xL and surviving } \\
\text { expression } \\
\text { Increased cleaved PARP expression }\end{array}$ & $25 \mu \mathrm{M}$ & [49] \\
\hline MDA-MB-231 & $\begin{array}{l}\text { Copper oxide nanowire conjugated } \\
\text { with folic acid }\end{array}$ & $\begin{array}{l}\text { FITC-annexin V/PI staining } \\
\text { assay }\end{array}$ & - & Induction of apoptosis & $2.5 \mu \mathrm{g} / \mathrm{mL}$ & [51] \\
\hline MDA-MB-231 & $\begin{array}{l}\text { Copper oxide nanowire conjugated } \\
\text { with folic acid }\end{array}$ & SEM & - & $\begin{array}{l}\text { Formation of apoptotic bodies and } \\
\text { membrane blebbing }\end{array}$ & $2.5 \mu \mathrm{g} / \mathrm{mL}$ & [51] \\
\hline MDA-MB-231 & $\begin{array}{l}\text { Copper oxide nanowire conjugated } \\
\text { with folic acid }\end{array}$ & Flow cytometry & - & Induction of ROS & $2.5 \mu \mathrm{g} / \mathrm{mL}$ & [51] \\
\hline MDA-MB-231 & $\begin{array}{l}\text { Copper oxide nanowire conjugated } \\
\text { with folic acid }\end{array}$ & $\begin{array}{l}\text { Mitochondrial membrane } \\
\text { potential (JC-1) } \\
\text { Immunofluorescence } \\
\text { Western blotting analysis } \\
\end{array}$ & $\begin{array}{l}\text { ROS } \\
\text { Cyt C }\end{array}$ & $\begin{array}{l}\text { Loss in the mitochondrial membrane } \\
\text { potential } \\
\text { Increased expression of Cyt } \mathrm{C} \text { in the } \\
\text { cytosol }\end{array}$ & $2.5 \mu \mathrm{g} / \mathrm{mL}$ & [51] \\
\hline MDA-MB-231 & $\begin{array}{l}\text { Copper oxide nanowire conjugated } \\
\text { with folic acid }\end{array}$ & Western blotting analysis & $\begin{array}{l}\text { Caspase } 3 \\
\text { Caspase } 9\end{array}$ & $\begin{array}{c}\text { Increased cleaved caspase } 9 \text { and caspase } 3 \\
\text { expression }\end{array}$ & $2.5 \mu \mathrm{g} / \mathrm{mL}$ & [51] \\
\hline MDA-MB-231 & $\begin{array}{l}\text { Copper oxide nanowire conjugated } \\
\text { with folic acid }\end{array}$ & $\begin{array}{l}\text { Western blotting analysis } \\
\text { Immuno-fluorescence staining }\end{array}$ & NF-кB p65 protein & $\begin{array}{l}\text { Inhibition of nuclear transport of the p65 } \\
\text { subunit of NF- } k B \text { protein }\end{array}$ & $2.5 \mu \mathrm{g} / \mathrm{mL}$ & [51] \\
\hline MDA-MB-231 & $\begin{array}{l}\text { Copper oxide nanowire conjugated } \\
\text { with folic acid }\end{array}$ & $\begin{array}{l}\text { qRT-PCR } \\
\text { Western blot }\end{array}$ & $\begin{array}{l}\text { miR425 } \\
\text { PTEN } \\
\text { Akt }\end{array}$ & $\begin{array}{l}\text { Down-regulation of miR- } 425 \text { and Akt, } \\
\text { and up-regulation of PTEN }\end{array}$ & $2.5 \mu \mathrm{g} / \mathrm{mL}$ & [51] \\
\hline MDA-MB-231 & $\begin{array}{c}\text { Ruthenium-based nucleolipidic } \\
\text { nanoaggregates }\end{array}$ & Phase-contrast microscopy & - & Cell shrinkage and loss of cell-cell contact & $14.7 \mu \mathrm{M}$ & [53] \\
\hline MDA-MB-231 & $\begin{array}{c}\text { Ruthenium-based nucleolipidic } \\
\text { nanoaggregates }\end{array}$ & $\begin{array}{l}\text { FITC-annexin V/PI staining } \\
\text { assay }\end{array}$ & - & $\sim 80 \%$ of cells in late apoptosis phase & $14.7 \mu \mathrm{M}$ & [53] \\
\hline MDA-MB-231 & $\begin{array}{l}\text { Ruthenium-based nucleolipidic } \\
\text { nanoaggregates }\end{array}$ & DNA fragmentation assay & - & Internucleosomal DNA laddering & $14.7 \mu \mathrm{M}$ & [53] \\
\hline MDA-MB-231 & $\begin{array}{l}\text { Ruthenium-based nucleolipidic } \\
\text { nanoaggregates }\end{array}$ & Western blot & $\begin{array}{c}\text { Bax } \\
\text { Bcl-2 } \\
\text { Caspase } 3 \\
\text { Caspase } 9 \\
\text { Caspase } 8\end{array}$ & $\begin{array}{c}\text { Up-regulated Bax expression } \\
\text { Down-regulated Bcl-2 expression } \\
\text { Activation of caspase } 9 \text {, caspase } 8 \text { and } \\
\text { caspase } 3\end{array}$ & $14.7 \mu \mathrm{M}$ & [53] \\
\hline $\begin{array}{l}\text { MDA-MB-231 } \\
\text { HCC1937 }\end{array}$ & Ruthenium complexes & RT-PCR & $\begin{array}{c}\text { P21 } \\
\text { p53 } \\
\text { BRCA1 }\end{array}$ & $\begin{array}{l}\text { Upregulated p53, P21 and BRCA1 } \\
\text { expression }\end{array}$ & $\begin{array}{c}13.2 \text { and } 14.1 \mu \mathrm{M} \text { for } \\
\text { MDA-MB-231; } \\
1.8 \text { and } 9.9 \mu \mathrm{M} \text { for } \\
\text { HCC } 1937\end{array}$ & [54] \\
\hline $\begin{array}{c}\text { A17 } \\
\text { MDA-MB-231 }\end{array}$ & Ruthenium complexes & $\begin{array}{l}\text { Immunohistochemistry } \\
\text { Western blot }\end{array}$ & Caspase 3 & $\begin{array}{l}\text { Increased number of apoptotic cells } \\
\text { (cleaved caspase } 3 \text { positive cells) }\end{array}$ & $\begin{array}{l}750 \mu \mathrm{M} \text { for A17; } \\
1 \mathrm{mM} \text { for } \\
\text { MDA-MB-231 }\end{array}$ & [55] \\
\hline
\end{tabular}


Table 3. Cont

\begin{tabular}{|c|c|c|c|c|c|c|}
\hline \multicolumn{7}{|c|}{ In Vitro } \\
\hline Cell Line & NPMBC & Assay & $\begin{array}{l}\text { Mode of } \\
\text { Action/Pathway } \\
\text { Involved }\end{array}$ & Effect Observed & Doses Assayed & Reference \\
\hline MDA-MB-231 & Ruthenium complexes & DAPI staining & - & $\begin{array}{l}\text { Nuclear chromatin condensation with } \\
\text { formation of apoptotic bodies }\end{array}$ & 2,4 and $8 \mu \mathrm{M}$ & [58] \\
\hline MDA-MB-231 & Ruthenium complexes & Flow cytometry (PE annexin-V) & - & $43 \%$ apoptotic cells & $2 \mu \mathrm{M}$ & [58] \\
\hline MDA-MB-231 & Ruthenium complexes & qRT-PCR & $\begin{array}{c}\text { Bax } \\
\text { Caspase } 3 \\
\text { Bcl-2 }\end{array}$ & $\begin{array}{l}\text { Increased Bax and caspase } 3 \text { expression } \\
\text { Decreased Bcl-2 expression }\end{array}$ & 4,8 and $16 \mu \mathrm{M}$ & {$[58]$} \\
\hline MDA-MB-231 & Ruthenium complexes & Western blotting & $\begin{array}{l}\text { Bax } \\
\text { Caspase } 3 \\
\text { Bcl-2 }\end{array}$ & $\begin{array}{c}\text { Increased Bax expression } \\
\text { Decreased Bcl-2 expression } \\
\text { No change in caspase-3 expression }\end{array}$ & $\begin{array}{c}0.5,1,2,4,8 \text { and } 16 \\
\mu \mathrm{M}\end{array}$ & [58] \\
\hline MDA-MB-231 & Ruthenium complexes & Comet assay & - & DNA damage & 4 and $8 \mu \mathrm{M}$ & {$[58]$} \\
\hline MDA-MB-231 & Ruthenium-based compounds & DAPI staining & - & Nuclear fragmentation & 60 and $70 \mu \mathrm{M}$ & [59] \\
\hline MDA-MB-231 & Ruthenium-based compounds & Flow cytometry (PE annexin-V) & - & $74.4 \%$ apoptotic cells & $20 \mu \mathrm{M}$ & [59] \\
\hline MDA-MB-231 & Ruthenium-based compounds & qRT-PCR & $\begin{array}{c}\text { Bax } \\
\text { Caspase } 3 \\
\text { Bcl-2 }\end{array}$ & $\begin{array}{c}\text { Increased expression of Bax and caspase } 3 . \\
\text { No change in } \\
\text { gene expression of Bcl-2 }\end{array}$ & $40 \mu \mathrm{M}$ & [59] \\
\hline MDA-MB-231 & Ruthenium-based compounds & Western blotting & Caspases 3 and 9 & Increased caspase 3 and 9 expression & $2.5 \mu \mathrm{M}$ & [59] \\
\hline MDA-MB-231 & Ruthenium-based compounds & Western blotting & Bcl-2 & No change in Bcl-2 expression & $10 \mu \mathrm{M}$ & [59] \\
\hline MDA-MB-231 & $\begin{array}{l}\text { Supermagnetic iron oxide } \\
\text { nanoparticles conjugated with } \\
\text { doxorubicin }\end{array}$ & $\begin{array}{l}\text { Mitochondrial membrane } \\
\text { potential (JC-1) }\end{array}$ & - & $\begin{array}{l}\text { Increased depolarization of mitochondrial } \\
\text { membrane potential }\end{array}$ & $520 \mu \mathrm{M}$ & {$[62]$} \\
\hline $\begin{array}{l}\text { MDA-MB-231 } \\
\text { HCC } 1806\end{array}$ & $\begin{array}{l}\text { Iron oxide nanoparticles linked } \\
\text { antagonist for leptin }\end{array}$ & Immunoblotting analysis & STAT3 & $\begin{array}{l}\text { Prevention of leptin-induced STAT3 } \\
\text { expression only in HCC1806 cells }\end{array}$ & $0.0036 \mathrm{pmol} / \mathrm{L}$ & [64] \\
\hline MDA-MB-231 & $\begin{array}{l}\text { Doxorubicin-hyaluronan conjugated } \\
\text { iron oxide nanoparticles }\end{array}$ & $\begin{array}{l}\text { FITC-annexin V/PI staining } \\
\text { assay }\end{array}$ & - & $\begin{array}{l}12 \% \text { apoptotic cells (early and late stages } \\
\text { of apoptosis) }\end{array}$ & $2 \mu \mathrm{M}$ & [65] \\
\hline MDA-MB-231 & $\begin{array}{l}\text { Doxorubicin-hyaluronan conjugated } \\
\text { iron oxide nanoparticles }\end{array}$ & $\begin{array}{l}\text { Steady-Glo luciferase reagent } \\
\text { assay }\end{array}$ & NF- $k B$ & $\begin{array}{l}\text { Reduced NF- } \mathrm{KB} \text { transcriptional activity } \\
\qquad(\sim 40 \%)\end{array}$ & $2 \mu \mathrm{M}$ & {$[65]$} \\
\hline MDA-MB-231 & Silver nanoparticles & $\begin{array}{l}\text { FITC-annexin V/PI staining } \\
\text { assay }\end{array}$ & - & Cells in early and late stages of apoptosis & $1.25-10 \mu \mathrm{g} / \mathrm{mL}$ & [67] \\
\hline MDA-MB-231 & Silver nanoparticles & Comet assay & - & DNA damage & 5 and $10 \mu \mathrm{g} / \mathrm{mL}$ & [67] \\
\hline MDA-MB-231 & Silver nanoparticles & $\begin{array}{l}\text { Flow cytometry } \\
\text { Confocal microscopy } \\
\text { Fluorescence microscopy }\end{array}$ & ROS & Increase ROS levels & $2.5,5$ and $10 \mu \mathrm{g} / \mathrm{mL}$ & [67] \\
\hline
\end{tabular}


Table 3. Cont.

\begin{tabular}{|c|c|c|c|c|c|c|}
\hline \multicolumn{7}{|c|}{ In Vitro } \\
\hline Cell Line & NPMBC & Assay & $\begin{array}{l}\text { Mode of } \\
\text { Action/Pathway } \\
\text { Involved }\end{array}$ & Effect Observed & Doses Assayed & Reference \\
\hline MDA-MB-231 & Rhodium(III) complex & Western blot & $\begin{array}{l}\text { Caspase } 3 \\
\text { Caspase } 7 \\
\text { Caspase } 8 \\
\text { Bcl-2 } \\
\text { PARP }\end{array}$ & $\begin{array}{c}\text { Increased PARP, and cleaved caspases-3, } \\
-7, \text { and }-8 \text { expression } \\
\text { Decreased Bcl-2 expression }\end{array}$ & 1 and $3 \mu \mathrm{M}$ & [69] \\
\hline \multicolumn{7}{|c|}{ In Vivo } \\
\hline Cell Line & NPMBC & $\begin{array}{l}\text { Animal (Model))/Analysis from } \\
\text { Animal Tissue }\end{array}$ & $\begin{array}{l}\text { Mode of } \\
\text { Action/Pathway } \\
\text { Involved }\end{array}$ & Effect Observed & $\begin{array}{l}\text { Doses Assayed } \\
\text { (Route of } \\
\text { Administration) }\end{array}$ & Reference \\
\hline MDA-MB-231 & $\begin{array}{l}\text { Liposome encapsulated ruthenium } \\
\text { polypyridine complex }\end{array}$ & $\begin{array}{l}\text { Athymic nude mice } \\
\text { (orthotopic)//Western blot, } \\
\text { immunohistochemistry }\end{array}$ & $\begin{array}{l}\text { PARP } \\
\text { Caspase } 3 \\
\text { Caspase } 8 \\
\text { Caspase } 9 \\
\text { TUNEL }\end{array}$ & $\begin{array}{c}\text { Increased TUNEL cleaved PARP, caspase } \\
3 \text {, caspase } 8 \text { and caspase } 9 \text { levels }\end{array}$ & $\begin{array}{c}5 \mathrm{mg} \text { ruthenium } / \mathrm{kg} \\
\text { (i.v.) }\end{array}$ & [16] \\
\hline MDA-MB-231 & $\begin{array}{l}\text { CD44-targeting HSP72 depletion } \\
\text { nanosystem based on plasmonic gold } \\
\text { nanoparticles }\end{array}$ & Immunohistochemistry & TUNEL & Massive apoptotic cells & $10 \mathrm{mg} / \mathrm{kg}$ (i.v.) & [28] \\
\hline MDA-MB-231 & Anti-EGFR-gold nanorod conjugates & $\begin{array}{l}\text { BALB/c nude mice (xenograft))/ } \\
\text { Immunohistochemistry }\end{array}$ & $\begin{array}{c}\text { TUNEL } \\
\text { Caspase } 3\end{array}$ & Increased TUNEL and caspase 3 levels & $\begin{array}{c}0.5 \mathrm{pmol} / \mathrm{g} \text { mouse } \\
\text { (i.v.) }\end{array}$ & [37] \\
\hline MDA-MB-231 & $\begin{array}{l}\text { Copper salicylate phenanthroline } \\
\text { complexes }\end{array}$ & $\begin{array}{l}\text { Nude mice (xenograft))/ } \\
\text { Immunohistochemical staining }\end{array}$ & $\begin{array}{c}\text { Bcl-2 } \\
\text { Bcl-xL } \\
\text { Survivin } \\
\end{array}$ & $\begin{array}{l}\text { Reduced Bcl-2, survivin and Bcl-xL } \\
\text { expression }\end{array}$ & $0.5 \mathrm{mg} / \mathrm{mL}$ (i.p.) & [49] \\
\hline $4 \mathrm{~T} 1$ & $\begin{array}{l}\text { Copper oxide nanowire conjugated } \\
\text { with folic acid }\end{array}$ & $\begin{array}{c}\text { Immunohistochemical analysis } \\
\text { of tumors of BALB/c mice } \\
\text { (orthotopic)) }\end{array}$ & - & $\begin{array}{l}\text { Suppression of tumor growth (lower } \\
\text { tumor weight and volume) }\end{array}$ & $\begin{array}{l}2.5 \mathrm{mg} / \mathrm{kg} \text { body } \\
\text { weight (i.p.) }\end{array}$ & [51] \\
\hline $4 \mathrm{~T} 1$ & $\begin{array}{l}\text { Copper oxide nanowire conjugated } \\
\text { with folic acid }\end{array}$ & $\begin{array}{l}\text { Immunohistochemical analysis } \\
\text { of tumors of BALB/c mice } \\
\text { (orthotopic)) /Immunohistochemical } \\
\text { analysis and western blot }\end{array}$ & $\begin{array}{c}\text { PTEN } \\
\text { miR425 }\end{array}$ & $\begin{array}{l}\text { Increased PTEN expression and } \\
\text { decreased miR-425 expression }\end{array}$ & $\begin{array}{l}2.5 \mathrm{mg} / \mathrm{kg} \text { body } \\
\text { weight (i.p.) }\end{array}$ & [51] \\
\hline A17 & Ruthenium complexes & $\begin{array}{c}\text { FVB/NCrl mice } \\
(\text { xenograft))/Immunohistochemistry } \\
\text { analysis }\end{array}$ & Caspase 3 & $\begin{array}{l}\text { Increased number of apoptotic cells in } \\
\text { tumors (cleaved caspase-3 positive cells) }\end{array}$ & $\begin{array}{l}210 \mathrm{mg} / \mathrm{kg} / \text { day } \\
\text { (i.p.) }\end{array}$ & [55] \\
\hline
\end{tabular}

Abbreviations: - , Not analyzed; 7-AAD, 7-Aminoactinomycin D; Akt, Protein Kinase B; Bax, Bcl-2-Like Protein 4; Bcl-2, B-Cell Lymphoma 2; Bcl-XL, B-Cell Lymphoma-Extra Large; BRCA1 Isothiocyanate; HSP72, Heat Shock Protein 72; i p, intraperitoneal injection; i.v., intravenous injection; miR425, microRNA425; NF- $k B$, Nuclear Factor Kappa-Light-Chain-Enhancer of Activated B Cells; 65 protein, Nuclear factor NF-kB P65 Subunit; PARP, Poly(ADP-ribose) POLYMERASE; PE, Phycoerythrin; PI, Propidium Iodide; PTEN, Phosphatase and Tensin Homolog; qRT-PCR, Quantitative Reverse Transcription Polymerase Chain Reaction; ROS, Reactive Oxygen Species; SEM, Scanning Electron Microscopy; STAT3, Signal Transducer and Activator of Transcription 3; TUNEL, Terminal Deosynucleotidyl Transferase dUTP Nick End Labeling. 
Table 4. Non-platinum metal based complexes (NPMBC) inhibit the in vitro and in vivo growth of triple-negative breast cancer (TNBC) cells by inducing autophagic cell death.

\begin{tabular}{|c|c|c|c|c|c|c|}
\hline \multicolumn{7}{|c|}{ In Vitro } \\
\hline Cell Line & NPMBC & Assay & $\begin{array}{l}\text { Mode of Action/Pathway } \\
\text { Involved }\end{array}$ & Effect Observed & Doses Assayed & Reference \\
\hline MDA-MB-231 & $\begin{array}{l}\text { Anti-EGFR-gold nanorod } \\
\text { conjugates }\end{array}$ & $\begin{array}{l}\text { Immunofluorescence } \\
\text { staining }\end{array}$ & LC3 & Increased LC3 expression & $120 \mathrm{pM}$ & [38] \\
\hline MDA-MB-231 & $\begin{array}{l}\text { Anti-EGFR-gold nanorod } \\
\text { conjugates }\end{array}$ & TEM & - & $\begin{array}{l}\text { Induction of double- or } \\
\text { multiple-membrane vesicles }\end{array}$ & $120 \mathrm{pM}$ & [38] \\
\hline MDA-MB-231 & $\begin{array}{l}\text { Anti-EGFR-gold nanorod } \\
\text { conjugates }\end{array}$ & Western blot & $\begin{array}{l}\text { Beclin-1 } \\
\text { Atg5 } \\
\text { p62 } \\
\text { LC3 } \\
\text { Akt } \\
\text { mTOR }\end{array}$ & $\begin{array}{l}\text { Increased Beclin-1, Atg5, LC3-II, } \\
\text { and p62 expression } \\
\text { Decreased phosphorylation of } \\
\text { mTOR and Akt }\end{array}$ & $120 \mathrm{pM}$ & [38] \\
\hline $\begin{array}{l}\text { MDA-MB-231 } \\
\text { SUM1315 }\end{array}$ & $\begin{array}{l}\text { Gold-nanoparticles conjugated } \\
\text { with Rad6 inhibitor }\end{array}$ & Western blot & $\begin{array}{l}\text { LC3-I } \\
\text { LC3-II } \\
\text { p62 }\end{array}$ & $\begin{array}{l}\text { Increased conversion of LC3-I to } \\
\text { LC3-II in SUM1315 cells } \\
\text { Decreased p62 expression in } \\
\text { SUM1315 cells } \\
\text { No changes in LC3-I/II ratios or } \\
\text { expression of p62 protein in } \\
\text { MDA-MB-231 cells }\end{array}$ & $1-5 \mu \mathrm{M}$ & [40] \\
\hline MDA-MB-231 & $\begin{array}{l}\text { Ruthenium-based nucleolipidic } \\
\text { nanoaggregates }\end{array}$ & $\begin{array}{l}\text { Phase-contrast microscopy } \\
\text { Monodansylcadaverine } \\
\text { assay }\end{array}$ & - & $\begin{array}{l}\text { Increased formation of autophagic } \\
\text { vacuoles }\end{array}$ & $12.1-14.7 \mu \mathrm{M}$ & [53] \\
\hline \multicolumn{7}{|c|}{ In Vivo } \\
\hline Cell Line & NPMBC & $\begin{array}{l}\text { Animal (Model)/Analysis } \\
\text { from Animal Tissue }\end{array}$ & $\begin{array}{l}\text { Mode of Action/Pathway } \\
\text { Involved }\end{array}$ & Effect Observed & $\begin{array}{l}\text { Doses Assayed (Route of } \\
\text { Administration) }\end{array}$ & Reference \\
\hline MDA-MB-231 & $\begin{array}{l}\text { Anti-EGFR-gold nanorod } \\
\text { conjugates }\end{array}$ & $\begin{array}{l}\text { BALB/c nude mice } \\
\text { (xenograft) }\end{array}$ & - & $\begin{array}{l}\text { Significant decrease in tumor } \\
\text { volume compared to control } \\
\left(120 \text { vs. } 250 \mathrm{~mm}^{3}\right)\end{array}$ & $0.5 \mathrm{pmol} / \mathrm{g}$ mouse (i.v.) & [38] \\
\hline MDA-MB-231 & $\begin{array}{l}\text { Anti-EGFR-gold nanorod } \\
\text { conjugates }\end{array}$ & $\begin{array}{c}\text { BALB/c nude mice } \\
\text { (xenograft)/Histological } \\
\text { analysis }\end{array}$ & $\begin{array}{l}\text { Beclin-1 } \\
\text { LC3 }\end{array}$ & $\begin{array}{l}\text { Enhanced beclin- } 1 \text { and } \\
\text { LC3 expression }\end{array}$ & $0.5 \mathrm{pmol} / \mathrm{g}$ mouse (i.v.) & [38] \\
\hline
\end{tabular}

Abbreviations: -, Not analyzed; Akt, Protein Kinase B; Atg5, Autophagy Related 5 Protein; EGFR, Epidermal Growth Factor Receptor; i.v., intravenous injection; LC3,

Microtubule-Associated Protein 1A/1B-Light Chain 3; mTOR, Mammalian Target of Rapamycin; p62, Nucleoporin p62; TEM, Transmission Electron Microscopy. 
Table 5. Non-platinum metal based complexes (NPMBC) inhibit the in vitro and in vivo growth of triple-negative breast cancer (TNBC) cells by inhibiting migration, invasion and/or metastasis.

\begin{tabular}{|c|c|c|c|c|c|c|}
\hline \multicolumn{7}{|c|}{ In Vitro } \\
\hline Cell Line & NPMBC & Assay & $\begin{array}{c}\text { Mode of } \\
\text { Action/Pathway } \\
\text { Involved }\end{array}$ & Effect Observed & Doses Assayed & Reference \\
\hline MDA-MB-231 & Chitosan layered gold nanorods & Transwell assay & - & Inhibition of cell migration & $50 \mathrm{nM}$ & [43] \\
\hline MDA-MB-231 & $\begin{array}{l}\text { Micellar gold nanoparticles } \\
\text { conjugated with ZD6474 }\end{array}$ & Boyden chamber assay & - & $\begin{array}{l}\sim 90 \% \text { inhibition of cell invasion } \\
\text { and migration }\end{array}$ & $1 \mu \mathrm{M}$ & [44] \\
\hline MDA-MB-231 & $\begin{array}{l}\text { Copper oxide nanowire } \\
\text { conjugated with folic acid }\end{array}$ & Wound healing assay & - & $85 \%$ inhibition of cell migration & $1.25 \mu \mathrm{g} / \mathrm{mL}$ & [51] \\
\hline MDA-MB-231 & $\begin{array}{l}\text { Copper oxide nanowire } \\
\text { conjugated with folic acid }\end{array}$ & Transwell migration assay & - & $80 \%$ inhibition of cell migration & $1.25 \mu \mathrm{g} / \mathrm{mL}$ & [51] \\
\hline MDA-MB-231 & $\begin{array}{l}\text { Copper oxide nanowire } \\
\text { conjugated with folic acid }\end{array}$ & Immunocytochemistry & $\begin{array}{l}\text { FAK } \\
\text { PTEN }\end{array}$ & $\begin{array}{c}\text { Decreased FAK expression } \\
\text { Up-regulated PTEN expression }\end{array}$ & $1.25 \mu \mathrm{g} / \mathrm{mL}$ & [51] \\
\hline MDA-MB-231 & Ruthenium-based complexes & Transwell assay & - & $90.8 \%$ inhibition of cell invasion & $4 \mu \mathrm{M}$ & [58] \\
\hline MDA-MB-231 & Ruthenium-based complexes & Wound healing assay & - & $79 \%$ inhibition of cell migration & $4 \mu \mathrm{M}$ & [58] \\
\hline MDA-MB-231 & Ruthenium-based complexes & Adhesion assay & $\begin{array}{l}\text { Type I collagen } \\
\text { Fibronectin } \\
\text { Laminin } \\
\text { Vitronectin }\end{array}$ & $\begin{array}{c}35-70 \% \text { inhibition of cancer cell } \\
\text { adhesion to extracellular matrix } \\
\text { proteins }\end{array}$ & $8 \mu$ & [58] \\
\hline MDA-MB-231 & Ruthenium-based complexes & Wound healing assay & - & Inhibition of cell migration & 5,10 and $20 \mu \mathrm{M}$ & [59] \\
\hline MDA-MB-231 & Ruthenium-based complexes & Transwell assay & - & $80 \%$ inhibition of cell invasion & $20 \mu \mathrm{M}$ & [59] \\
\hline MDA-MB-231 & Ruthenium-based complexes & Zymography assay & MMP-9 & $\begin{array}{l}60 \% \text { of inhibition of MMP-9 } \\
\text { expression }\end{array}$ & $20 \mu \mathrm{M}$ & [59] \\
\hline MDA-MB-231 & Ruthenium-based complexes & Adhesion assay & $\begin{array}{c}\text { Type I collagen } \\
\text { Fibronectin } \\
\text { Laminin } \\
\text { Vitronectin }\end{array}$ & $\begin{array}{l}50-65 \% \text { inhibition of cancer cell } \\
\text { adhesion to type I collagen, } \\
\text { fibronectin, laminin, vitronectin }\end{array}$ & $40 \mu \mathrm{M}$ & [59] \\
\hline $\begin{array}{l}\text { MDA-MB-231 } \\
\quad 4 \mathrm{~T} 1\end{array}$ & $\begin{array}{c}\text { Supermagnetic iron oxide } \\
\text { nanoparticles conjugated with } \\
\text { doxorubicin }\end{array}$ & Wound healing assay & - & Minimal closure of the scratch & $520 \mu \mathrm{M}$ & [62] \\
\hline MDA-MB-231 & $\begin{array}{c}\text { Doxorubicin-hyaluronan } \\
\text { conjugated iron oxide } \\
\text { nanoparticles }\end{array}$ & Confocal microscopy & $\begin{array}{l}\text { Vimentin } \\
\text { e-cadherin }\end{array}$ & $\begin{array}{l}\text { Decreased vimentin expression } \\
\text { No change in e-cadherin } \\
\text { expression }\end{array}$ & $2 \mu \mathrm{M}$ & [65] \\
\hline MDA-MB-231 & $\begin{array}{l}\text { Doxorubicin-hyaluronan } \\
\text { conjugated iron oxide } \\
\text { nanoparticles }\end{array}$ & ELISA & $\begin{array}{l}\text { IL-6 } \\
\text { IL-10 }\end{array}$ & $\begin{array}{l}\text { Decreased IL-6 secretion } \\
\text { No change in secretion of IL-10 }\end{array}$ & $2 \mu \mathrm{M}$ & [65] \\
\hline
\end{tabular}


Table 5. Cont.

\begin{tabular}{|c|c|c|c|c|c|c|}
\hline \multicolumn{7}{|c|}{ In Vitro } \\
\hline Cell Line & NPMBC & Assay & $\begin{array}{c}\text { Mode of } \\
\text { Action/Pathway } \\
\text { Involved }\end{array}$ & Effect Observed & Doses Assayed & Reference \\
\hline MDA-MB-231 & $\begin{array}{l}\text { Doxorubicin-hyaluronan } \\
\text { conjugated iron oxide } \\
\text { nanoparticles }\end{array}$ & Steady-Glo luciferase reagent assay & NF- $k B$ & $\begin{array}{l}\text { Reduced NF- } \kappa \text { B transcriptional } \\
\text { activity }(\sim 40 \%)\end{array}$ & $2 \mu \mathrm{M}$ & {$[65]$} \\
\hline \multicolumn{7}{|c|}{ In Vivo } \\
\hline Cell Line & NPMBC & $\begin{array}{c}\text { Animal (Model)/Analysis from } \\
\text { Animal Tissue }\end{array}$ & $\begin{array}{c}\text { Mode of } \\
\text { Action/Pathway } \\
\text { Involved }\end{array}$ & Effect Observed & $\begin{array}{l}\text { Doses Assayed (Route } \\
\text { of Administration) }\end{array}$ & Reference \\
\hline T41 & Iron oxide nanoparticles & $\begin{array}{c}\text { BALB/c immune-competent mice } \\
\text { (xenograft) }\end{array}$ & - & $\begin{array}{l}\text { Lower lung metastatic nodules } \\
\text { than control (13 vs. } 42)\end{array}$ & $\begin{array}{c}20 \mathrm{mg} \text { iron } / \mathrm{kg} \text { body } \\
\text { weight (i.v.) }\end{array}$ & [61] \\
\hline SUM159 & Iron oxide nanoparticles & $\begin{array}{l}\text { NOD/SCID immune-compromised } \\
\text { mice (orthotopic) }\end{array}$ & - & $\begin{array}{c}\text { Lower incidence of lymph node } \\
\text { metastasis than control ( } 25 \% \mathrm{vs} \text {. } \\
62.5 \%)\end{array}$ & $\begin{array}{l}20 \mathrm{mg} \text { iron } / \mathrm{kg} \text { body } \\
\text { weight (i.v.) }\end{array}$ & {$[61]$} \\
\hline $4 \mathrm{~T} 1$ & $\begin{array}{l}\text { Supermagnetic iron oxide } \\
\text { nanoparticles conjugated with } \\
\text { doxorubicin }\end{array}$ & BALB/c mice (orthotopic) & $\alpha v \beta 3$ & $\begin{array}{c}\text { Lower metastatic colonies than } \\
\text { control ( } \sim<1 \text { vs. } \sim 10 \text { at lung } \\
\text { respectively; } \sim 1 \text { vs. } \sim 3 \text { at liver } \\
\text { respectively) which could be } \\
\text { related with the inhibition of } \\
\alpha \mathrm{v} \beta 3\end{array}$ & $\begin{array}{c}0.25 \mathrm{mg} \text { iron } / 100 \mathrm{~mm}^{3} \\
\text { (i.t.) }\end{array}$ & {$[62]$} \\
\hline
\end{tabular}

Matrix Metalloproteinases; NF-kB, Nuclear Factor Kappa-Light-Chain-Enhancer of Activated B Cells; PKM, Pyruvate Kinase Isozymes; PTEN, Phosphatase and Tensin Homolog. 
Cellular studies constitute an important step in the development of drugs; however, demonstrating efficacy in suitable animal models and validating cellular observations in vivo are a condition sine qua non for clinical trials investigating potential anticancer agents. Inconsistencies in results between in vitro and in vivo systems concerning the anticancer effect of NPMBC can be related to differences in their pharmacokinetic behavior, thus their study is necessary. In this way, NPMBC seem to have good in vivo pharmacokinetic properties. They are absorbed quickly into plasma $[16,39,44,52]$, the circulation time in the bloodstream is long [42], their uptake in the tumor tissue is significant $[16,28,32,37,39,41,42$, $44,46,51,52,60,70]$, their accumulation in organs (brain, liver, kidney, spleen, heart, lung, and intestine) is low $[16,28,39,41,42,44,51,52,55]$ and the clearing rate is good [51].

A large proportion of current knowledge about the therapeutic potential of NPMBC is derived from in vitro and in vivo studies performed using TNBC cell lines. TNBC MDA-MB-231 cell models are considered the most reliable models of TNBC [71,72], so this cell line is the world's most commonly used human TNBC cell line. However, this raises the issue on how representative this cell line is of the broad spectrum of TNBCs (Table 1).

\subsection{Suppression of Cancer Cell Viability in Association with the Induction of Cell Death}

NPMBC-mediated inhibition of breast carcinogenesis is associated with reduced cellular proliferation (Table 2) together with the induction of programmed cell death (Tables 3 and 4). Apoptosis is by far the primary mode of programmed cell death (Table 3), but sometimes it is coupled to the induction of autophagy, as can be suspected from the few studies which have been carried out (Table 4).

NPMBC display good cytotoxic behavior in vitro and are able to reduce the growth of primary tumors (Table 2). NPMBC inhibit the growth of TNBC cells better than non-TNBC cells [66]. Furthermore, NPMBC of which effects are dose- $[49,53,55,67]$ and time- $[63,67]$ dependent could be more cytotoxic than platinum-based drugs [52,53,57,58,68]. For example, Biancalana et al. [57] observed that ruthenium complexes have good cytotoxic activity, with $\mathrm{IC}_{50}$ values substantially lower than the values obtained with cisplatin on MDA-MB-231 cells. These differences could be due to the fact that they have different mechanisms of action; for example, the activation of p53-dependent or p53-independent checkpoints by cisplatin or ruthenium complexes, respectively $[9,52,54,68]$. Since platinum-based drugs and NPMBC act on different pathways, NPMBC could be a new therapeutic option for patients with TNBC resistant to platinum-based drugs.

Avoiding apoptosis is a hallmark of cancer and an important mechanism in resistance to therapies. Apoptosis is preferred over necrosis because the latter elicits inflammation and undesirable immunogenic responses [73]. NPMBC induce significant apoptotic activity in TNBC cells which can be mediated by multiple mechanisms (Table 3). When MDA-MB-231 and BT-20 cells were treated with $25 \mu \mathrm{M}$ copper salicylate phenanthroline complexes, more than $80 \%$ of TNBC cells underwent apoptosis through down-regulation of the anti-apoptosis proteins $\mathrm{Bcl}-2, \mathrm{Bcl}-\mathrm{xL}$ and survivin and up-regulation of cleaved PARP [49]. These findings confirm the participation of protease enzyme caspases in the programmed cell death induced by NPMBC. However, NPMBC can also activate caspase-independent pathways acting on mitochondria. For example, when MDA-MB-231 cells were treated with $10 \mu \mathrm{g} / \mathrm{mL}$ of silver nanoparticles, high intracellular levels of reactive oxygen species (ROS) were observed at $24 \mathrm{~h}$ of incubation [67]. These free radicals destabilize the mitochondria and induce apoptosis [74] acting on Bcl-2 family proteins [75]. Considering that TNBC is more susceptible to drugs that cause oxidative stress than other BC types [66], these compounds could be a hopeful alternative method for its treatment. Besides what was mentioned above, we must not forget that the efficacy of several NPMBC relies on their capacity to influence the tumor-host interaction and modify the immune microenvironment, inducing a form of apoptosis in cancer cells known as "immunogenic cell death". Thus, Montani et al. [55] observed that ruthenium complexes reverse tumor-associated immune suppression leading to the activation of an immune response specific for TNBC cells.

The NPMBC can be synthesized by chemical [76], physical [77] and biological methods [35], all with cytotoxic activity against TNBC cells. Although chemical and physical syntheses have been 
the most widely used strategies, there is growing interest in the biosynthesis of NPMBC because of its numerous advantages (for example, economical, safe, and inert) [78,79].

The NPMBC differ in shape [34], size [31-33,42], dose [30,36,66], synthesis procedure (see previous paragraph), composition [50,56], capping agent [33,80], particle surface charges [31] and structure $[56,68,69]$. All of these features can affect their cellular uptake and therefore also their cytotoxic activity. In general, modified small nanoparticles with low surface charges $(-15 \mathrm{mV})$ have better cellular internalization than large nanoparticles, however both extremely small $(<25 \mathrm{~nm})$ and large $(>80 \mathrm{~nm})$ nanoparticles displayed a low cellular uptake [31,33]. On the other hand, it has been demonstrated that replacing ruthenium with iron gives compounds with high antiproliferative activity $\left(\mathrm{IC}_{50}=0.09\right.$ vs. $\left.>30 \mu \mathrm{M}\right)$, the compounds with the shortest carbon chain linking the two cyclopentadienyl rings being the most active [56]. Finally, another interesting finding is the superiority of nanorods over nanospheres for photothermal cancer therapy (PCT) using gold nanoparticles [34]. Despite this evidence, it has not been possible to establish a linear correlation between cellular responses and the characteristics of NPMBC because there is wide interstudy variability (for example, in relation to cell lines, measurement methods, etc.).

NPMBC possess cytotoxic activity per se $[39,66,67,69]$; however, their main applications are related to their ability to act as radiosensitizers in cancer cells through the induction of G2/M phase cell cycle arrest $[36,47,66]$, as agents for PCT applications $[14,28,29,37,63]$ or as transmembrane carriers for the controlled release and targeted delivery of anticancer drugs increasing their cellular uptake [30, $39,40]$, among others $[47,64]$. Cancer cells in a tumor are very heterogeneous, that is, they differ in marker expression, morphology, proliferation capacity, growth stage, etc. This heterogeneity increases the need for combining therapeutic agents with different action mechanisms. Although few studies have examined the role of NPMBC for combination chemotherapy, recently the utility of iron oxide magnetic nanoparticles as multidrug codelivery system for synergistic chemotherapy has been demonstrated [63].

The effects of NPMBC on TNBC cells, as well as on cancer cells from other solid tumors, is facilitated by abnormalities of the tumor vasculature, such as hypervascularization, high production of vascular permeability factors, etc. [81]. However, intrinsic properties of NPMBC are not less important. For example, nanoparticles are characterized by their high permeability [82] and retention effect [83] which results in potentiation of the cytotoxic effects with minimal side effects [39,49]. When the tyrosine kinase inhibitor ZD6474 was conjugated with gold nanoparticles, besides inducing a higher antiproliferative effect than the ZD6474 alone under in vitro conditions, it also reduced the size of tumors induced in mice more efficiently than the drug alone [44]. These properties could be useful to counteract drug resistance mechanisms, the main limitation to the success of conventional therapy. In this sense, Conde et al. [41] showed that gold nanoparticles loaded with 5-fluorouracil $\left(\mathrm{IC}_{50}=\sim 0.5 \mathrm{nM}\right)$ decrease the viability of 5-fluorouracil-resistant MDA-MB-231 cells by silencing the cell surface efflux pump MRP1.

One of the concerns for developing NPMBC as therapeutic agents for TNBC treatment could be their toxicity. However, several studies have proven their harmlessness in normal cells $[39,49,52,57,66,84]$. Ruthenium(II) paracyme complexes showed a moderate selectivity for TNBC cells, so normal cells (human skin fibroblasts) were less affected than MDA-MB-231 cells [57]. Likewise, when copper salicylate phenanthroline complexes [49], ruthenium complexes [55] or gold nanoparticles [28,37,39] were administered to mice, they were well tolerated as evidenced by the lack of weight loss, behavior of the animal or examination of organs.

It is hypothesized that, because of their capacity for self-renewal, differentiation and apoptosis-resistance [85], cancer stem cells (CSCs, also referred to as tumor-initiating cells) could be responsible for the cancer formation [61]. What is more, they could be resistant to conventional treatments and contribute to the recurrence after treatment [86]. Gold nanoshells seem to sensitize breast CSCs to radiation therapy mediated by the activation of the heat shock proteins (HSP) HSP40, HSP60, HSP70 and HSP90 $\alpha$ [45]. Likewise, CSCs' ability to self-renew might be inhibited by iron 
oxide nanoparticle-mediated PCT [61] or iron oxide nanoparticles-linked leptin antagonist [64] which has been demonstrated through the reduction of mammospheres/tumorspheres of MDA-MB-231 and SUM 159 cells $[61,64]$. Although these findings are hopeful, new strategies for improving the intratumoral distribution of NPMBC are necessary to achieve a homogeneous nanoparticle distribution within the tumor without depositing them in surrounding healthy tissue [70].

\subsection{Migration, Invasion and/or Metastasis}

Metastasis is a cascade of events where tumor cells disseminate from the primary tumor to distant sites, with the migration of tumor cells being a prerequisite for tumor-cell invasion and metastasis (Figure 1) [87]. Thus, any factor which regulates this process might be a target for anti-metastatic therapeutic strategies (Table 5). The poor prognosis of the triple negative subtype reflects the aggressive biology of this disease and the difficulty of its treatment, especially when it metastasizes.

Study of the anti-metastatic effect of NPMBC on TNBC cells is very recent. It has been shown that NPMBC, besides enhancing the potential of anticancer therapies $[43,44,62]$, can be used as monotherapy $[43,51]$ to prevent cancer cell migration, invasion and/or metastasis. These findings were confirmed by Paholak et al. [61] using in vivo models. When immunocompromised NOD/SCID mice were inoculated with TNBC cells, it was observed that those mice that received nanoparticle-mediated PCT prior to surgical tumor resection had lower incidence of metastasis to the lung than those which had been treated only with surgery. If these findings were observed in humans, combination therapy consisting of nanoparticle-mediated PCT and surgery would provide a treatment option for patients with metastatic breast cancer, a disease which nowadays has no cure [88].

Unfortunately, little is known about the mechanisms underlying the anti-metastatic effect of NPMBC (Figure 1 and Table 5). However, available evidence suggests that their action could be mediated by the inhibition of matrix metalloproteinases (MMPs) [59], enzymes with the ability to degrade extracellular matrix proteins, after interaction with the $\alpha \mathrm{v} \beta 3$ integrin receptor [62]. Likewise, it has been suggested that NPMBC could inhibit epithelial-mesenchymal transition [65] and modify the structure of the actin cytoskeleton, interfering with the function of integrins [58,59] and under-regulating the phosphorylation of the focal adhesion kinase (FAK) [51]. No less important are the studies which highlight their role in inflammation $[89,90]$. On the one hand, it has been observed that doxorubicin-hyaluronan conjugated iron oxide nanoparticles reduce the secretion of the pro-inflammatory IL-6, an important prognostic indicator in patients with TNCB [91], and which is thought to contribute to their invasiveness [92]; on the other hand, it has been suggested that iron oxide nanoparticle-mediated hyperthermia could trigger the release of inflammatory mediators which would induce a systemic cancer-specific immune response in which cytotoxic T-cells would recognize and inhibit distal cancer cells [89].

One of the major limitations of anti-metastatic chemotherapy, as has already been mentioned for the treatment of primary tumors, is the toxicity which underlies the importance of targeted therapies. Anticancer drugs should be delivered and act only at the site of action. In this respect, nanoparticles are worthy of mention because they more effectively inhibit the migration of TNBC cells compared to non-tumor cells [51]. Sarkar et al. [44] found potentiation of the anti-migration and anti-invasion effect of the tyrosine kinase inhibitor ZD6474 when it was conjugated to gold nanoparticles synthesized in micellar networks of an amphiphilic block copolymer. On the other hand, the conjugation of interfering RNA (siRNA) to nanoparticles in order to suppress the expression of proteins is another interesting approach. It has been shown that chitosan-layered gold nanorods can be used for silencing genes related to the invasion of TNBC cells [43]. Another strategy which enables the selectivity for tumor cells to be enhanced is by attaching nanoparticles to ligands that bind to receptors expressed on the surface of cancer cells, as has been highlighted by Ahir et al. [51]. Considering that folate receptor expression is elevated in BC cells [93], this receptor could be a good target for cancer treatment. Copper oxide nanowires conjugated with folic acid prevent the motility of MDA-MB-231 cells, an effect that has been validated in vivo [51]. 


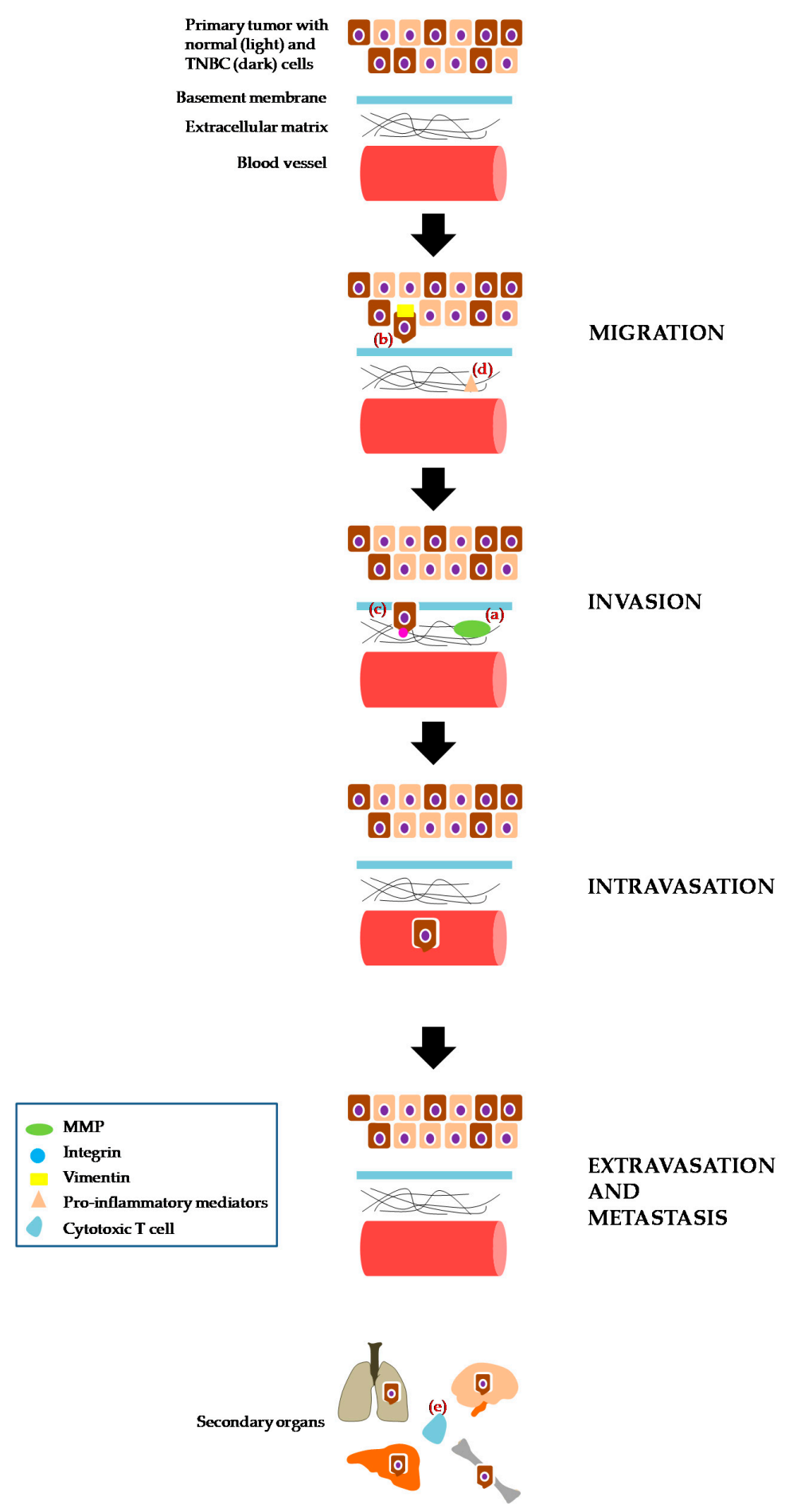

Figure 1. Schematic representation of the metastatic process in triple negative breast cancer (TNBC) and its inhibition by non-platinum metal-based complexes (NPMBC). Metastasis is a sequential and interrelated multi-step process that consists of four main essential steps: migration to adjacent tissue after detachment from a primary tumor; local invasion of cancer cells into adjacent tissue; trans-endothelial migration of cancer cells into vessels (intravasation); transport of cancer cells through the circulatory system with extravasation of them in a secondary organ (brain, lung, liver, bone). The anti-metastatic effect of NPMBC has been associated with their ability: to inhibit matrix metalloproteinases (a); to inhibit mesenchymal markers such as vimentin (b); to interfere with the function of integrins (c); and to modify the immune/inflammatory response (d,e). 


\section{Conclusions}

Anticancer drugs with new molecular mechanisms of action are necessary for chemotherapy treatment of TNBC, with NPMBC emerging as an upcoming treatment modality. It has been suggested that NPMBC could have an effect on different TNBC cell lines, both in vitro and in vivo. In this way, it has been shown that NPMBC are responsible for activating programmed cell death and exhibiting activity against metastasis. Despite these findings, more studies with different cell lines are required to explore other pathways which could contribute to the control of the broad spectrum of TNBC.

Author Contributions: E.M.D.M. contributed substantially to the conception of the work, analysis of data, drafting, critical revision and supervision of the submitted manuscript. D.G.M.-M. contributed substantially to the conception of the work, analysis of data, drafting and critical revision of the submitted manuscript. L.V.-G. and D.L.-A. contributed substantially to the design of the work, acquisition and analysis of data, and drafting of the submitted manuscript. M.J.N.-I. contributed substantially to the design of the work, acquisition, analysis and interpretation of data, and drafting of the submitted manuscript. M.F.-G. contributed substantially to the conception of the work, interpretation of data and critical revision of the submitted manuscript. S.N. contributed substantially to the analysis and interpretation of data, design, drafting, critical revision and supervision of the submitted manuscript. Furthermore, all authors have approved the final version to be published and are accountable for all aspects of the work in ensuring that questions related to the accuracy or integrity of any part of the work are appropriately investigated, resolved and documented in the literature.

Funding: This research received no external funding.

Conflicts of Interest: The authors declare no conflict of interest.

\section{References}

1. World Health Organization. Breast Cancer. Available online: http://www.who.int/cancer/prevention/ diagnosis-screening/breast-cancer/en/ (accessed on 27 July 2018).

2. Howell, A.; Anderson, A.S.; Clarke, R.B.; Duffy, S.W.; Evans, D.G.; Garcia-Closas, M.; Gescher, A.J.; Key, T.J.; Saxton, J.M.; Harvie, M.N. Risk Determination and Prevention of Breast Cancer. Breast Cancer Res. 2014, 16, 446. [CrossRef] [PubMed]

3. Ricks-Santi, L.; McDonald, J.T.; Gold, B.; Dean, M.; Thompson, N.; Abbas, M.; Wilson, B.; Kanaan, Y.; Naab, T.J.; Dunston, G. Next Generation Sequencing Reveals High Prevalence of BRCA1 and BRCA2 Variants of Unknown Significance in Early-Onset Breast Cancer in African American Women. Ethn. Dis. 2017, 27, 169-178. [CrossRef] [PubMed]

4. Dai, X.; Cheng, H.; Bai, Z.; Li, J. Breast Cancer Cell Line Classification and Its Relevance with Breast Tumor Subtyping. J. Cancer 2017, 8, 3131-3141. [CrossRef] [PubMed]

5. Zaha, D.C. Significance of Immunohistochemistry in Breast Cancer. World J. Clin. Oncol. 2014, 5, 382-392. [CrossRef] [PubMed]

6. Aysola, K.; Desai, A.; Welch, C.; Xu, J.; Qin, Y.; Reddy, V.; Matthews, R.; Owens, C.; Okoli, J.; Beech, D.J.; et al. Triple Negative Breast Cancer-An Overview. Hered. Genet. 2013, 2013. [CrossRef]

7. Sharma, P. Update on the Treatment of Early-Stage Triple-Negative Breast Cancer. Curr. Treat. Options Oncol. 2018, 19, 22. [CrossRef] [PubMed]

8. Miller, E.; Lee, H.J.; Lulla, A.; Hernandez, L.; Gokare, P.; Lim, B. Current Treatment of Early Breast Cancer: Adjuvant and Neoadjuvant Therapy. F1000Res 2014, 3, 198. [CrossRef] [PubMed]

9. Hongthong, K.; Ratanaphan, A. BRCA1-Associated Triple-Negative Breast Cancer and Potential Treatment for Ruthenium-Based Compounds. Curr. Cancer Drug Targets 2016, 16, 606-617. [CrossRef] [PubMed]

10. Chavez, K.J.; Garimella, S.V.; Lipkowitz, S. Triple Negative Breast Cancer Cell Lines: One Tool in the Search for Better Treatment of Triple Negative Breast Cancer. Breast Dis. 2010, 32, 35-48. [CrossRef] [PubMed]

11. Lehmann, B.D.; Bauer, J.A.; Chen, X.; Sanders, M.E.; Chakravarthy, A.B.; Shyr, Y.; Pietenpol, J.A. Identification of Human Triple-Negative Breast Cancer Subtypes and Preclinical Models for Selection of Targeted Therapies. J. Clin. Investig. 2011, 121, 2750-2767. [CrossRef] [PubMed]

12. Neve, R.M.; Chin, K.; Fridlyand, J.; Yeh, J.; Baehner, F.L.; Fevr, T.; Clark, L.; Bayani, N.; Coppe, J.P.; Tong, F.; et al. A Collection of Breast Cancer Cell Lines for the Study of Functionally Distinct Cancer Subtypes. Cancer Cell 2006, 10, 515-527. [CrossRef] [PubMed] 
13. Jiang, G.; Zhang, S.; Yazdanparast, A.; Li, M.; Pawar, A.V.; Liu, Y.; Inavolu, S.M.; Cheng, L. Comprehensive Comparison of Molecular Portraits Between Cell Lines and Tumors in Breast Cancer. BMC Genomics 2016, 17, 525. [CrossRef] [PubMed]

14. Webb, J.A.; Ou, Y.C.; Faley, S.; Paul, E.P.; Hittinger, J.P.; Cutright, C.C.; Lin, E.C.; Bellan, L.M.; Bardhan, R. Theranostic Gold Nanoantennas for Simultaneous Multiplexed Raman Imaging of Immunomarkers and Photothermal Therapy. ACS Omega 2017, 2, 3583-3594. [CrossRef] [PubMed]

15. Tao, Y.; Li, M.; Auguste, D.T. Pattern-Based Sensing of Triple Negative Breast Cancer Cells with Dual-Ligand Cofunctionalized Gold Nanoclusters. Biomaterials 2017, 116, 21-33. [CrossRef] [PubMed]

16. Shen, J.; Kim, H.C.; Wolfram, J.; Mu, C.; Zhang, W.; Liu, H.; Xie, Y.; Mai, J.; Zhang, H.; Li, Z.; et al. A Liposome Encapsulated Ruthenium Polypyridine Complex as a Theranostic Platform for Triple-Negative Breast Cancer. Nano Lett. 2017, 17, 2913-2920. [CrossRef] [PubMed]

17. Zhao, Y.; Pang, B.; Luehmann, H.; Detering, L.; Yang, X.; Sultan, D.; Harpstrite, S.; Sharma, V.; Cutler, C.S.; Xia, Y.; et al. Gold Nanoparticles Doped with (199) Au Atoms and Their Use for Targeted Cancer Imaging by SPECT. Adv. Healthc. Mater. 2016, 5, 928-935. [CrossRef] [PubMed]

18. Zhang, M.; Kim, H.S.; Jin, T.; Yi, A.; Moon, W.K. Ultrasound-Guided Photoacoustic Imaging for the Selective Detection of EGFR-Expressing Breast Cancer and Lymph Node Metastases. Biomed. Opt. Express 2016, 7, 1920-1931. [CrossRef] [PubMed]

19. Abulrob, A.; Corluka, S.; Blasiak, B.; Gino Fallone, B.; Ponjevic, D.; Matyas, J.; Tomanek, B. LyP-1 Conjugated Nanoparticles for Magnetic Resonance Imaging of Triple Negative Breast Cancer. Mol. Imaging Biol. 2018, 20, 428-435. [CrossRef] [PubMed]

20. Guo, P.; Huang, J.; Wang, L.; Jia, D.; Yang, J.; Dillon, D.A.; Zurakowski, D.; Mao, H.; Moses, M.A.; Auguste, D.T. ICAM-1 as a Molecular Target for Triple Negative Breast Cancer. Proc. Natl. Acad. Sci. USA 2014, 111, 14710-14715. [CrossRef] [PubMed]

21. Pang, B.; Zhao, Y.; Luehmann, H.; Yang, X.; Detering, L.; You, M.; Zhang, C.; Zhang, L.; Li, Z.Y.; Ren, Q.; et al. ${ }^{64} \mathrm{Cu}$-Doped PdCu@Au Tripods: A Multifunctional Nanomaterial for Positron Emission Tomography and Image-Guided Photothermal Cancer Treatment. ACS Nano 2016, 10, 3121-3131. [CrossRef] [PubMed]

22. Ndagi, U.; Mhlongo, N.; Soliman, M.E. Metal Complexes in Cancer Therapy-An Update from Drug Design Perspective. Drug Des. Dev. Ther. 2017, 11, 599-616. [CrossRef] [PubMed]

23. Wang, D.; Lippard, S.J. Cellular Processing of Platinum Anticancer Drugs. Nat. Rev. Drug Discov. 2005, 4, 307-320. [CrossRef] [PubMed]

24. Birkbak, N.J.; Wang, Z.C.; Kim, J.Y.; Eklund, A.C.; Li, Q.; Tian, R.; Bowman-Colin, C.; Li, Y.; Greene-Colozzi, A.; Iglehart, J.D.; et al. Telomeric Allelic Imbalance Indicates Defective DNA Repair and Sensitivity to DNA-Damaging Agents. Cancer Discov. 2012, 2, 366-375. [CrossRef] [PubMed]

25. Silver, D.P.; Richardson, A.L.; Eklund, A.C.; Wang, Z.C.; Szallasi, Z.; Li, Q.; Juul, N.; Leong, C.O.; Calogrias, D.; Buraimoh, A.; et al. Efficacy of Neoadjuvant Cisplatin in Triple-Negative Breast Cancer. J. Clin. Oncol. 2010, 28, 1145-1153. [CrossRef] [PubMed]

26. Ciarimboli, G. Membrane Transporters as Mediators of Cisplatin Side-Effects. Anticancer Res. 2014, 34, 547-550. [CrossRef] [PubMed]

27. Dam, D.H.; Culver, K.S.; Odom, T.W. Grafting Aptamers onto Gold Nanostars Increases in vitro Efficacy in a Wide Range of Cancer Cell Types. Mol. Pharm. 2014, 11, 580-587. [CrossRef] [PubMed]

28. Wang, S.; Tian, Y.; Tian, W.; Sun, J.; Zhao, S.; Liu, Y.; Wang, C.; Tang, Y.; Ma, X.; Teng, Z.; et al. Selectively Sensitizing Malignant Cells to Photothermal Therapy Using a CD44-Targeting Heat Shock Protein 72 Depletion Nanosystem. ACS Nano 2016, 10, 8578-8590. [CrossRef] [PubMed]

29. Ou, Y.C.; Webb, J.A.; Faley, S.; Shae, D.; Talbert, E.M.; Lin, S.; Cutright, C.C.; Wilson, J.T.; Bellan, L.M.; Bardhan, R. Gold Nanoantenna-Mediated Photothermal Drug Delivery from Thermosensitive Liposomes in Breast Cancer. ACS Omega 2016, 1, 234-243. [CrossRef] [PubMed]

30. Santiago, T.; DeVaux, R.S.; Kurzatkowska, K.; Espinal, R.; Herschkowitz, J.I.; Hepel, M. Surface-Enhanced Raman Scattering Investigation of Targeted Delivery and Controlled Release of Gemcitabine. Int. J. Nanomed. 2017, 12, 7763-7776. [CrossRef] [PubMed]

31. Saw, W.S.; Ujihara, M.; Chong, W.Y.; Voon, S.H.; Imae, T.; Kiew, L.V.; Lee, H.B.; Sim, K.S.; Chung, L.Y. Size-Dependent Effect of Cystine/Citric Acid-Capped Confeito-Like Gold Nanoparticles on Cellular Uptake and Photothermal Cancer Therapy. Colloids Surf. B Biointerfaces 2018, 161, 365-374. [CrossRef] [PubMed] 
32. Ayala-Orozco, C.; Urban, C.; Bishnoi, S.; Urban, A.; Charron, H.; Mitchell, T.; Shea, M.; Nanda, S.; Schiff, R.; Halas, N.; et al. Sub-100 nm Gold Nanomatryoshkas Improve Photo-Thermal Therapy Efficacy in Large and Highly Aggressive Triple Negative Breast Tumors. J. Control. Release 2014, 191, 90-97. [CrossRef] [PubMed]

33. Kong, T.; Zeng, J.; Wang, X.; Yang, X.; Yang, J.; McQuarrie, S.; McEwan, A.; Roa, W.; Chen, J.; Xing, J.Z. Enhancement of Radiation Cytotoxicity in Breast-Cancer Cells by Localized Attachment of Gold Nanoparticles. Small 2008, 4, 1537-1543. [CrossRef] [PubMed]

34. Dube, E.; Oluwole, D.O.; Nwaji, N.; Nyokong, T. Glycosylated Zinc Phthalocyanine-Gold Nanoparticle Conjugates for Photodynamic Therapy: Effect of Nanoparticle Shape. Spectrochim. Acta A Mol. Biomol. Spectrosc. 2018, 203, 85-95. [CrossRef] [PubMed]

35. Dozie-Nwachukwu, S.O.; Obayemi, J.D.; Danyuo, Y.; Anuku, N.; Odusanya, O.S.; Malatesta, K.; Soboyejo, W.O. A Comparative Study of the Adhesion of Biosynthesized Gold and Conjugated Gold/Prodigiosin Nanoparticles to Triple Negative Breast Cancer Cells. J. Mater. Sci. Mater. Med. 2017, 28, 143. [CrossRef] [PubMed]

36. Wang, C.; Jiang, Y.; Li, X.; Hu, L. Thioglucose-Bound Gold Nanoparticles Increase the Radiosensitivity of a Triple-Negative Breast Cancer Cell Line (MDA-MB-231). Breast Cancer 2015, 22, 413-420. [CrossRef] [PubMed]

37. Zhang, M.; Kim, H.S.; Jin, T.; Woo, J.; Piao, Y.J.; Moon, W.K. Near-Infrared Photothermal Therapy Using Anti-EGFR-Gold Nanorod Conjugates for Triple Negative Breast Cancer. Oncotarget 2017, 8, 86566-86575. [CrossRef] [PubMed]

38. Zhang, M.; Kim, H.S.; Jin, T.; Moon, W.K. Near-Infrared Photothermal Therapy Using EGFR-Targeted Gold Nanoparticles Increases Autophagic Cell Death in Breast Cancer. J. Photochem. Photobiol. B. 2017, 170, 58-64. [CrossRef] [PubMed]

39. Malik, M.T.; O’Toole, M.G.; Casson, L.K.; Thomas, S.D.; Bardi, G.T.; Reyes-Reyes, E.M.; Ng, C.K.; Kang, K.A.; Bates, P.J. AS1411-Conjugated Gold Nanospheres and Their Potential for Breast Cancer Therapy. Oncotarget 2015, 6, 22270-22281. [CrossRef] [PubMed]

40. Haynes, B.; Zhang, Y.; Liu, F.; Li, J.; Petit, S.; Kothayer, H.; Bao, X.; Westwell, A.D.; Mao, G.; Shekhar, M.P.V. Gold Nanoparticle Conjugated Rad6 Inhibitor Induces Cell Death in Triple Negative Breast Cancer Cells by Inducing Mitochondrial Dysfunction and PARP-1 Hyperactivation: Synthesis and Characterization. Nanomedicine 2016, 12, 745-757. [CrossRef] [PubMed]

41. Conde, J.; Oliva, N.; Artzi, N. Implantable Hydrogel Embedded Dark-Gold Nanoswitch as a Theranostic Probe to Sense and Overcome Cancer Multidrug Resistance. Proc. Natl. Acad. Sci. USA 2015, 112, E1278-E1287. [CrossRef] [PubMed]

42. Ayala-Orozco, C.; Urban, C.; Knight, M.W.; Urban, A.S.; Neumann, O.; Bishnoi, S.W.; Mukherjee, S.; Goodman, A.M.; Charron, H.; Mitchell, T.; et al. Au Nanomatryoshkas as Efficient Near-Infrared Photothermal Transducers for Cancer Treatment: Benchmarking Against Nanoshells. ACS Nano 2014, 8, 6372-6381. [CrossRef] [PubMed]

43. Yang, Z.; Liu, T.; Xie, Y.; Sun, Z.; Liu, H.; Lin, J.; Liu, C.; Mao, Z.W.; Nie, S. Chitosan Layered Gold Nanorods as Synergistic Therapeutics for Photothermal Ablation and Gene Silencing in Triple-Negative Breast Cancer. Acta Biomater. 2015, 25, 194-204. [CrossRef] [PubMed]

44. Sarkar, S.; Konar, S.; Prasad, P.N.; Rajput, S.; Kumar, B.N.P.; Rao, R.R.; Pathak, A.; Fisher, P.B.; Mandal, M. Micellear Gold Nanoparticles as Delivery Vehicles for Dual Tyrosine Kinase Inhibitor ZD6474 for Metastatic Breast Cancer Treatment. Langmuir 2017, 33, 7649-7659. [CrossRef] [PubMed]

45. Atkinson, R.L.; Zhang, M.; Diagaradjane, P.; Peddibhotla, S.; Contreras, A.; Hilsenbeck, S.G.; Woodward, W.A.; Krishnan, S.; Chang, J.C.; Rosen, J.M. Thermal Enhancement with Optically Activated Gold Nanoshells Sensitizes Breast Cancer Stem Cells to Radiation Therapy. Sci. Transl. Med. 2010, 2. [CrossRef] [PubMed]

46. Zhao, N.; Yang, Z.; Li, B.; Meng, J.; Shi, Z.; Li, P.; Fu, S. RGD-Conjugated Mesoporous Silica-Encapsulated Gold Nanorods Enhance the Sensitization of Triple-Negative Breast Cancer to Megavoltage Radiation Therapy. Int. J. Nanomed. 2016, 11, 5595-5610. [CrossRef] [PubMed]

47. Lee, J.; Chatterjee, D.K.; Lee, M.H.; Krishnan, S. Gold Nanoparticles in Breast Cancer Treatment: Promise and Potential Pitfalls. Cancer Lett. 2014, 347, 46-53. [CrossRef] [PubMed] 
48. Klassen, N.V.; Kedrov, V.V.; Ossipyan, Y.A.; Shmurak, S.Z.; Shmyt Ko, I.M.; Krivko, O.A.; Kudrenko, E.A.; Kurlov, V.N.; Kobelev, N.P.; Kiselev, A.P.; et al. Nanoscintillators for Microscopic Diagnostics of Biological and Medical Objects and Medical Therapy. IEEE Trans. Nanobiosci. 2009, 8, 20-32. [CrossRef] [PubMed]

49. Fan, L.; Tian, M.; Liu, Y.; Deng, Y.; Liao, Z.; Xu, J. Salicylate •Phenanthroline Copper (II) Complex Induces Apoptosis in Triple-Negative Breast Cancer Cells. Oncotarget 2017, 8, 29823-29832. [CrossRef] [PubMed]

50. Afrasiabi, Z.; Stovall, P.; Finley, K.; Choudhury, A.; Barnes, C.; Ahmad, A.; Sarkar, F.; Vyas, A.; Padhye, S. Targeting Triple Negative Breast Cancer Cells by N3-Substituted 9,10-Phenanthrenequinone Thiosemicarbazones and Their Metal Complexes. Spectrochim. Acta A Mol. Biomol. Spectrosc. 2013, 114, 114-119. [CrossRef] [PubMed]

51. Ahir, M.; Bhattacharya, S.; Karmakar, S.; Mukhopadhyay, A.; Mukherjee, S.; Ghosh, S.; Chattopadhyay, S.; Patra, P.; Adhikary, A. Tailored-CuO-Nanowire Decorated with Folic Acid Mediated Coupling of the Mitochondrial-ROS Generation and miR425-PTEN Axis in Furnishing Potent Anti-Cancer Activity in Human Triple Negative Breast Carcinoma Cells. Biomaterials 2016, 76, 115-132. [CrossRef] [PubMed]

52. Frik, M.; Martínez, A.; Elie, B.T.; Gonzalo, O.; Ramírez de Mingo, D.; Sanaú, M.; Sánchez-Delgado, R.; Sadhukha, T.; Prabha, S.; Ramos, J.W.; et al. In Vitro and in Vivo Evaluation of Water-Soluble Iminophosphorane Ruthenium(II) Compounds. A Potential Chemotherapeutic Agent for Triple Negative Breast Cancer. J. Med. Chem. 2014, 57, 9995-10012. [CrossRef] [PubMed]

53. Irace, C.; Misso, G.; Capuozzo, A.; Piccolo, M.; Riccardi, C.; Luchini, A.; Caraglia, M.; Paduano, L.; Montesarchio, D.; Santamaria, R. Antiproliferative Effects of Ruthenium-Based Nucleolipidic Nanoaggregates in Human Models of Breast Cancer in Vitro: Insights into Their Mode of Action. Sci. Rep. 2017, 7, 45236. [CrossRef] [PubMed]

54. Nhukeaw, T.; Temboot, P.; Hansongnern, K.; Ratanaphan, A. Cellular Responses of BRCA1-Defective and Triple-Negative Breast Cancer Cells and in Vitro BRCA1 Interactions Induced by Metallo-Intercalator Ruthenium(II) Complexes Containing Chloro-Substituted Phenylazopyridine. BMC Cancer 2014, 14, 73. [CrossRef] [PubMed]

55. Montani, M.; Pazmay, G.V.B.; Hysi, A.; Lupidi, G.; Pettinari, R.; Gambini, V.; Tilio, M.; Marchetti, F.; Pettinari, C.; Ferraro, S.; et al. The Water Soluble Ruthenium(II) Organometallic Compound $[\mathrm{Ru}(\mathrm{p}$-cymene)(bis(3,5 dimethylpyrazol-1-yl)methane)Cl]Cl Suppresses Triple Negative Breast Cancer Growth by Inhibiting Tumor Infiltration of Regulatory T Cells. Pharmacol. Res. 2016, 107, 282-290. [CrossRef] [PubMed]

56. Beauperin, M.; Top, S.; Richard, M.A.; Plażuk, D.; Pigeon, P.; Toma, S.; Poláčková, V.; Jaouen, G. The Length of the Bridging Chain in Ansa-Metallocenes Influences Their Antiproliferative Activity Against Triple Negative Breast Cancer Cells (TNBC). Dalton Trans. 2016, 45, 13126-13134. [CrossRef] [PubMed]

57. Biancalana, L.; Zacchini, S.; Ferri, N.; Lupo, M.G.; Pampaloni, G.; Marchetti, F. Tuning the Cytotoxicity of Ruthenium(Ii) Para-Cymene Complexes by Mono-Substitution at a Triphenylphosphine/ Phenoxydiphenylphosphine Ligand. Dalton Trans. 2017, 46, 16589-16604. [CrossRef] [PubMed]

58. Becceneri, A.B.; Popolin, C.P.; Plutin, A.M.; Maistro, E.L.; Castellano, E.E.; Batista, A.A.; Cominetti, M.R. The Trans-[Ru(PPh3)2(N,N-dimethyl-N'-thiophenylthioureato-k2O,S)(bipy)]PF6 Complex Has Pro-Apoptotic Effects on Triple Negative Breast Cancer Cells and Presents Low Toxicity in Vivo. J. Inorg Biochem. 2018, 186, 70-84. [CrossRef] [PubMed]

59. Popolin, C.P.; Reis, J.P.B.; Becceneri, A.B.; Graminha, A.E.; Almeida, M.A.P.; Corrêa, R.S.; Colina-Vegas, L.A.; Ellena, J.; Batista, A.A.; Cominetti, M.R. Cytotoxicity and Anti-Tumor Effects of New Ruthenium Complexes on Triple Negative Breast Cancer Cells. PLoS ONE 2017, 12, e0183275. [CrossRef] [PubMed]

60. Chen, H.; Burnett, J.; Zhang, F.; Zhang, J.; Paholak, H.; Sun, D. Highly Crystallized Iron Oxide Nanoparticles as Effective and Biodegradable Mediators for Photothermal Cancer Therapy. J. Mater. Chem. B 2014, 2, 757-765. [CrossRef]

61. Paholak, H.J.; Stevers, N.O.; Chen, H.; Burnett, J.P.; He, M.; Korkaya, H.; McDermott, S.P.; Deol, Y.; Clouthier, S.G.; Luther, T.; et al. Elimination of Epithelial-Like and Mesenchymal-Like Breast Cancer Stem Cells to Inhibit Metastasis Following Nanoparticle-Mediated Photothermal Therapy. Biomaterials 2016, 104, 145-157. [CrossRef] [PubMed]

62. Manigandan, A.; Handi, V.; Sundaramoorthy, N.S.; Dhandapani, R.; Radhakrishnan, J.; Sethuraman, S.; Subramanian, A. Responsive Nanomicellar Theranostic Cages for Metastatic Breast Cancer. Bioconjug. Chem. 2018, 29, 275-286. [CrossRef] [PubMed] 
63. Xie, W.; Gao, Q.; Guo, Z.; Wang, D.; Gao, F.; Wang, X.; Wei, Y.; Zhao, L. Injectable and Self-Healing Thermosensitive Magnetic Hydrogel for Asynchronous Control Release of Doxorubicin and Docetaxel to Treat Triple-Negative Breast Cancer. ACS Appl. Mater. Interfaces 2017, 9, 33660-33673. [CrossRef] [PubMed]

64. Harmon, T.; Harbuzariu, A.; Lanier, V.; Lipsey, C.C.; Kirlin, W.; Yang, L.; Gonzalez-Perez, R.R. Nanoparticle-Linked Antagonist for Leptin Signaling Inhibition in Breast Cancer. World J. Clin. Oncol. 2017, 8, 54-66. [CrossRef] [PubMed]

65. Vyas, D.; Lopez-Hisijos, N.; Gandhi, S.; El-Dakdouki, M.; Basson, M.D.; Walsh, M.F.; Huang, X.; Vyas, A.K.; Chaturvedi, L.S. Doxorubicin-Hyaluronan Conjugated Super-Paramagnetic Iron Oxide Nanoparticles (DOX-HA-SPION) Enhanced Cytoplasmic Uptake of Doxorubicin and Modulated Apoptosis, IL-6 Release and NF-KappaB Activity in Human MDA-MB-231 Breast Cancer Cells. J. Nanosci. Nanotechnol. 2015, 15, 6413-6422. [CrossRef] [PubMed]

66. Swanner, J.; Mims, J.; Carroll, D.L.; Akman, S.A.; Furdui, C.M.; Torti, S.V.; Singh, R.N. Differential Cytotoxic and Radiosensitizing Effects of Silver Nanoparticles on Triple-Negative Breast Cancer and Non-Triple-Negative Breast Cells. Int. J. Nanomed. 2015, 10, 3937-3953. [CrossRef]

67. Juarez-Moreno, K.; Gonzalez, E.B.; Girón-Vazquez, N.; Chávez-Santoscoy, R.A.; Mota-Morales, J.D.; Perez-Mozqueda, L.L.; Garcia-Garcia, M.R.; Pestryakov, A.; Bogdanchikova, N. Comparison of Cytotoxicity and Genotoxicity Effects of Silver Nanoparticles on Human Cervix and Breast Cancer Cell Lines. Hum. Exp. Toxicol. 2017, 36, 931-948. [CrossRef] [PubMed]

68. Hearn, J.M.; Hughes, G.M.; Romero-Canelón, I.; Munro, A.F.; Rubio-Ruiz, B.; Liu, Z.; Carragher, N.O.; Sadler, P.J. Pharmaco-Genomic Investigations of Organo-Iridium Anticancer Complexes Reveal Novel Mechanism of Action. Metallomics 2018, 10, 93-107. [CrossRef] [PubMed]

69. Yang, G.J.; Zhong, H.J.; Ko, C.N.; Wong, S.Y.; Vellaisamy, K.; Ye, M.; Ma, D.L.; Leung, C.H. Identification of a Rhodium(III) Complex as a Wee1 Inhibitor Against TP53-Mutated Triple-Negative Breast Cancer Cells. Chem. Commun. 2018, 54, 2463-2466. [CrossRef] [PubMed]

70. Mooney, R.; Roma, L.; Zhao, D.; van Haute, D.; Garcia, E.; Kim, S.U.; Annala, A.J.; Aboody, K.S.; Berlin, J.M. Neural Stem Cell-Mediated Intratumoral Delivery of Gold Nanorods Improves Photothermal Therapy. ACS Nano 2014, 8, 12450-12460. [CrossRef] [PubMed]

71. Lacroix, M.; Leclercq, G. Relevance of Breast Cancer Cell Lines as Models for Breast Tumours: An Update. Breast Cancer Res. Treat. 2004, 83, 249-289. [CrossRef] [PubMed]

72. Holliday, D.L.; Speirs, V. Choosing the Right Cell Line for Breast Cancer Research. Breast Cancer Res. 2011, 13, 215. [CrossRef] [PubMed]

73. Rock, K.L.; Kono, H. The Inflammatory Response to Cell Death. Annu. Rev. Pathol. 2008, 3, 99-126. [CrossRef] [PubMed]

74. Mammucari, C.; Rizzuto, R. Signaling Pathways in Mitochondrial Dysfunction and Aging. Mech. Ageing Dev. 2010, 131, 536-543. [CrossRef] [PubMed]

75. Sohur, U.S.; Dixit, M.N.; Chen, C.L.; Byrom, M.W.; Kerr, L.A. Rel/NF-KappaB Represses Bcl-2 Transcription in Pro-B Lymphocytes. Gene Expr. 1999, 8, 219-229. [PubMed]

76. Selvakannan, P.R.; Mandal, S.; Pasricha, R.; Adyanthaya, S.D.; Sastry, M. One-Step Synthesis of Hydrophobized Gold Nanoparticles of Controllable Size by the Reduction of Aqueous Chloroaurate Ions by Hexadecylaniline at the Liquid-Liquid Interface. Chem. Commun. 2002, 13, 1334-1335. [CrossRef]

77. Okitsu, K.; Yue, A.; Tanabe, S.; Matsumoto, H.; Yobiko, Y. Formation of Colloidal Gold Nanoparticles in an Ultrasonic Field: Control of Rate of Gold (III) Reduction and Size of Formed Gold Particles. Langmuir 2001, 17,7717-7720. [CrossRef]

78. Korbekandi, H.; Ashari, Z.; Iravani, S.; Abbasi, S. Optimization of Biological Synthesis of Silver Nanoparticles Using Fusarium Oxysporum. Iran J. Pharm. Res. 2013, 12, 289-298. [PubMed]

79. Iravani, S.; Korbekandi, H.; Mirmohammadi, S.V.; Zolfaghari, B. Synthesis of Silver Nanoparticles: Chemical, Physical and Biological Methods. Res. Pharm. Sci. 2014, 9, 385-406. [PubMed]

80. Lesniak, A.; Kilinc, D.; Rashdan, S.A.; von Kriegsheim, A.; Ashall, B.; Zerulla, D.; Kolch, W.; Lee, G.U. In Vitro Study of the Interaction of Heregulin-Functionalized Magnetic-Optical Nanorods with MCF7 and MDA-MB-231 Cells. Faraday Discuss. 2014, 175, 189-201. [CrossRef] [PubMed]

81. Greish, K. Enhanced Permeability and Retention (EPR) Effect for Anticancer Nanomedicine Drug Targeting. Methods Mol. Biol. 2010, 624, 25-37. [CrossRef] [PubMed] 
82. Matsumura, Y.; Maeda, H. A New Concept for Macromolecular Therapeutics in Cancer Hemotherapy: Mechanism of Tumoritropic Accumulation of Proteins and the Antitumor Agent Smancs. Cancer Res. 1986, 46, 6387-6392. [PubMed]

83. Maeda, H.; Wu, J.; Sawa, T.; Matsumura, Y.; Hori, K. Tumor Vascular Permeability and the EPR Effect in Macromolecular Therapeutics: A Review. J. Control. Release 2000, 65, 271-284. [CrossRef]

84. Dam, D.H.; Culver, K.S.; Kandela, I.; Lee, R.C.; Chandra, K.; Lee, H.; Mantis, C.; Ugolkov, A.; Mazar, A.P.; Odom, T.W. Biodistribution and in Vivo Toxicity of Aptamer-Loaded Gold Nanostars. Nanomedicine 2015, 11, 671-679. [CrossRef] [PubMed]

85. Cioce, M.; Gherardi, S.; Viglietto, G.; Strano, S.; Blandino, G.; Muti, P.; Ciliberto, G. Mammosphere-Forming Cells from Breast Cancer Cell Lines as a Tool for the Identification of CSC-Like- and Early Progenitor-Targeting Drugs. Cell Cycle 2010, 9, 2878-2887. [CrossRef] [PubMed]

86. Rosen, J.M.; Jordan, C.T. The Increasing Complexity of the Cancer Stem Cell Paradigm. Science 2009, 324, 1670-1673. [CrossRef] [PubMed]

87. Bravo-Cordero, J.J.; Hodgson, L.; Condeelis, J. Directed Cell Invasion and Migration during Metastasis. Curr. Opin. Cell Biol. 2012, 24, 277-283. [CrossRef] [PubMed]

88. Anampa, J.; Sparano, J.A. New Agents for the Management of Resistant Metastatic Breast Cancer. Expert Opin. Pharmacother. 2017, 18, 1815-1831. [CrossRef] [PubMed]

89. Toraya-Brown, S.; Sheen, M.R.; Zhang, P.; Chen, L.; Baird, J.R.; Demidenko, E.; Turk, M.J.; Hoopes, P.J.; Conejo-Garcia, J.R.; Fiering, S. Local Hyperthermia Treatment of Tumors Induces CD8(+) T Cell-Mediated Resistance Against Distal and Secondary Tumors. Nanomedicine 2014, 10, 1273-1285. [CrossRef] [PubMed]

90. Aggarwal, B.B.; Shishodia, S.; Sandur, S.K.; Pandey, M.K.; Sethi, G. Inflammation and Cancer: How Hot Is the Link? Biochem. Pharmacol. 2006, 72, 1605-1621. [CrossRef] [PubMed]

91. Salgado, R.; Junius, S.; Benoy, I.; van Dam, P.; Vermeulen, P.; van Marck, E.; Huget, P.; Dirix, L.Y. Circulating Interleukin-6 Predicts Survival in Patients with Metastatic Breast Cancer. Int. J. Cancer 2003, 103, 642-646. [CrossRef] [PubMed]

92. Berberoglu, U.; Yildirim, E.; Celen, O. Serum Levels of Tumor Necrosis Factor Alpha Correlate with Response to Neoadjuvant Chemotherapy in Locally Advanced Breast Cancer. Int. J. Biol. Markers 2004, 19, 130-134. [CrossRef] [PubMed]

93. Hartmann, L.C.; Keeney, G.L.; Lingle, W.L.; Christianson, T.J.; Varghese, B.; Hillman, D.; Oberg, A.L.; Low, P.S. Folate Receptor Overexpression Is Associated with Poor Outcome in Breast Cancer. Int. J. Cancer 2007, 121, 938-942. [CrossRef] [PubMed] 